\title{
Fluid migration recorded by fluid inclusions in crack-sealed quartz veins and sandstone host rock; Cameros Basin, Spain
}

\author{
Laura González-Acebrón ${ }^{1}\left[\right.$ Maialen Lopez-Elorza ${ }^{1,3} \cdot$ Ramón Mas $^{1,3} \cdot$ José Arribas $^{2,3} \cdot$ Silvia Omodeo-Salé $^{4}$
}

Received: 31 October 2020 / Accepted: 20 July 2021 / Published online: 11 August 2021

(c) The Author(s) 2021

\begin{abstract}
The role of deep hydrothermal fluid circulation through fractures and their impact on the sandstone host rock is studied in an extensional sedimentary basin (Cameros Basin, Spain) affected by a post-extensional hydrothermal metamorphism. The quartzarenites of the Urbión Group constituted a hydrocarbon carrier affected by very low to low-grade hydrothermal metamorphism during Late Albian to Coniacian. This process generated abundant quartz veins and transformed the quartzarenites into quartzites. This study compares the microthermometry of the fluid inclusion asemblages (FIAs) in the veins and in the quartz grain overgrowths in the quartzites, in order to understand the behavior of the hydrothermal fluids through fractures and their effects in the host rock. Fluid inclusions in the quartz grain overgrowths contain liquid and vapor at room temperature and homogenize to the liquid $\left(T_{\mathrm{h}}: 124-265^{\circ} \mathrm{C}, \mathrm{H}_{2} \mathrm{O}+\mathrm{NaCl}\right.$ system). Those of quartz veins present both liquid and vapor $\mathrm{CO}_{2}$ and an aqueous liquid phase (room temperature). Final homogenization is to the liquid $\left(T_{\mathrm{h}}\right.$ : $109-282{ }^{\circ} \mathrm{C}, \mathrm{H}_{2} \mathrm{O}+\mathrm{NaCl}+\mathrm{CO}_{2}$, mean values of amount-of-substance fractions: $0.92,0.01,0.07$ ). Large $T_{\mathrm{h}}$ variation within each FIA is common, due to crack and sealing processes and to reequilibration by successive thermal pulses. In contrast, the narrow $T_{\mathrm{h}}$ range in each FIA towards the top of the record indicates that these inclusions are probably not reequilibrated. Two growing stages are recognized under SEM-CL in the quartz grain overgrowths, one diagenetic and another hydrothermal, the later with FIAs showing $T_{\mathrm{h}}$ similar than the veins. The results can help in the evaluation of the geo-energy resources in sedimentary basins.
\end{abstract}

Keywords Quartz cement · Fluid inclusions · Hydrothermal veins $\cdot$ SEM-CL $\cdot$ Cameros Basin

\section{Resumen}

Este estudio aborda el papel de la circulación hidrotermal a través de las fracturas y su impacto en las areniscas encajantes en una cuenca sedimentaria extensional (Cuenca de Cameros, España) afectada por un metamorfismo hidrotermal postextensional. Las cuarzoarenitas del Grupo Urbión constituyeron un camino de migración de hidrocarburos que fue afectado por un metamorfismo hidrotermal de grado muy bajo a bajo durante el Albiense tardío-Coniaciense. Este proceso generó abundantes venas de cuarzo y transformó las cuarzoarenitas en cuarcitas. Este estudio compara la microtermometría de las asociaciones de inclusiones fluidas (FIAs según sus siglas en inglés) en las venas y en los cementos de los granos de cuarzo de las cuarcitas, para comprender el comportamiento de los fluidos hidrotermales a lo largo de las fracturas y su efecto en la roca caja. Las inclusiones fluidas en los cementos de los granos de cuarzo contienen líquido y vapor a temperatura de habitación y homogenizan a fase líquida $\left(T_{\mathrm{h}}: 124-265^{\circ} \mathrm{C}\right.$, sistema $\left.\mathrm{H}_{2} \mathrm{O}+\mathrm{NaCl}\right)$. Las de las venas de cuarzo presentan tanto $\mathrm{CO}_{2}$ líquido como vapor, y una fase líquida acuosa a temperatura de habitación. Su homogenización final es a fase líquida $\left(T_{\mathrm{h}}\right.$ : 109-282 ${ }^{\circ} \mathrm{C}, \mathrm{H}_{2} \mathrm{O}+\mathrm{NaCl}+\mathrm{CO}_{2}$, valores medios de cantidad de sustancia: 0.92, 0.01, 0.07). Existe una amplia variación de $T_{\mathrm{h}}$ dentro de cada FIA, debido a los procesos de apertura y cierre de fracturas y a la reequilibración por los sucesivos pulsos

Laura González-Acebrón

lgcebron@geo.ucm.es

1 Departamento de Geodinámica, Estratigrafía y Paleontología, Facultad de Ciencias Geológicas UCM, C/ Jose Antonio Novais 12, 28040 Madrid, Spain

2 Departamento de Mineralogía y Petrología, Facultad de Ciencias Geológicas (UCM), Madrid, Spain
3 Instituto de Geociencias (CSIC), IGEO (CSIC, UCM), C/Severo Ochoa 7, 28040 Madrid, Spain

4 GE-RGBA Group, Department of Earth Sciences, University of Geneva, Rue de Maraîchers 13, 1205 Geneva, Switzerland 
hidrotermales. Sin embargo, el estrecho rango de variación de $T_{\mathrm{h}}$ dentro de cada FIA hacia techo del registro indica que estas inclusiones probablemente no están reequilibradas. Se pueden reconocer dos estadios de crecimiento en los cementos de los granos de cuarzo mediante SEM-CL, uno diagenético y otro hidrotermal, este último con FIAs con $T_{\mathrm{h}}$ similares a las de las venas. Estos resultados pueden ser útiles en la evaluación de recursos de geo-energía en cuencas sedimentarias.

Palabras clave Cemento de cuarzo $\cdot$ Inclusiones fluidas $\cdot$ Venas hidrotermales $\cdot$ SEM-CL $\cdot$ Cuenca de Cameros

\section{Introduction}

Fracture opening may provide transient fluid migration pathways in sedimentary basins, including deep circulation of aqueous liquid, oil and gas. The study of fracture sealing by mineralization and the temperatures of the circulating fluids is a main task in exploration. Stronger attention has been paid to carbonate veins (e.g. Duncan et al., 2012; Hooker et al., 2012; Müller et al., 2000) in comparison to quartz (e.g. Fall et al., 2012; Laubach et al., 2004), because widespread cold cathodoluminiscence and staining procedures allow determining growth stages in carbonate veins. In addition, depending on their orientation, and especially when they are sealed, fractures represent discontinuity surfaces inside sedimentary successions, which may control fluid migration across certain surfaces. Cemented fractures may be associated to either extensional or compressional tectonic features, and may reflect complex tectonic histories. Crack-seal veins develop by repeated increments of microcrack opening, followed by sealing due to precipitation of material from solution (Ramsay, 1980). Crack-sealing cements are useful to reconstruct episodes of fracture opening and cement precipitation to help establish fracture propagation timing (Becker et al., 2010; Fall et al., 2012).

This study concentrates on the influence of deep hydrothermal fluid circulation through fractures and their impact on the sandstone host rock. To our best knowledge, this is the first work comparing fluid inclusion microthermometry in quartz veins and quartz overgrowths generated in the original sandstone.

This research is focussed on fluid inclusions in quartz veins and quartz grain overgrowths both hosted in the upper Berriasian to upper Barremian quartzite of the Urbión Group (Mas et al., 2004). Sandstones of the Urbión Group were deposited in the eastern sector of the Cameros Basin (North Spain) (Figs. 1 and 2). In the eastern sector of this basin, during the post-extensional phase, a large part of the sedimentary record was affected by hydrothermal metamorphism (e.g. Casquet et al., 1992; González-Acebrón et al., 2011; Mantilla-Figueroa et al., 2002).

In the unit most affected by metamorphism (the Urbión Group, late Berriasian to early Aptian in age), the part of its stratigraphic record that includes from the late Berriasian to the late Barremian was studied (Fig. 2). Abundant quartzfilled fractures have been observed in the field, cross-cutting the main stratification (Fig. 3). These veins have been interpreted as forming during the hydrothermal process in extensional fractures (Casquet et al., 1992) or during the extensional stage of basin formation (García-Lasanta et al., 2014; Guiraud \& Seguret, 1985; Mantilla-Figueroa, 1999; Mata et al., 2001). Previous fluid inclusion studies of the Urbión Group have been focused either in the quartz veins (Mantilla-Figueroa, 1999; Mata et al., 2001) or in the quartz grain overgrowths (Ochoa, 2006; Ochoa et al., 2007), whereas a comparison of both systems has not yet been done.

The principal aims of this paper are: (1) to compare thermal histories of the fracture fillings and the host rock in the Cameros Basin, taking in consideration both diagenetic and hydrothermal processes; (2) to characterize the water-rock interaction in hydrothermal systems; and (3) to determine the pressure of entrapment of primary fluid inclusions and correlate to hydrothermal processes. In order to achieve these objectives new fluid inclusion petrography and microthermometry data are provided for both, quartz veins and quartz grain overgrowths in the host sandstone. The fluid inclusion data of previous publications (Mantilla-Figueroa, 1999; Mata et al., 2001; Ochoa, 2006; Ochoa et al., 2007) have been integrated in the discussion.

\section{Geological and stratigraphic setting}

\subsection{Basin formation}

The Cameros Basin in the northern Iberian Range (Fig. 1a) forms part of the Mesozoic Iberian Extensional System (Guimerà et al., 1995; Mas et al., 1993, 2002, 2019; Salas et al., 2001). Intraplate rifting was a consequence of a generalized extensional regime, which separated Iberia from Europe.

The basin formed in the second extensional phase, which ranged from Tithonian to early Albian (Mas et al., 1993, 2003) (Fig. 1c). The subsidence and sedimentation rates in the Cameros Basin were very high, with the deposition of a vertical thickness up to $6500 \mathrm{~m}$, and up to $9000 \mathrm{~m}$ of stratigraphic record in the direction of northward migration of basin depocenters (Guimerà et al., 1995; Mas et al., 1993, 2003, 2019; Omodeo-Salé et al., 2014). The basin has been interpreted as an extensional ramp syncline basin, formed on a south-dipping ramp associated with a buried 


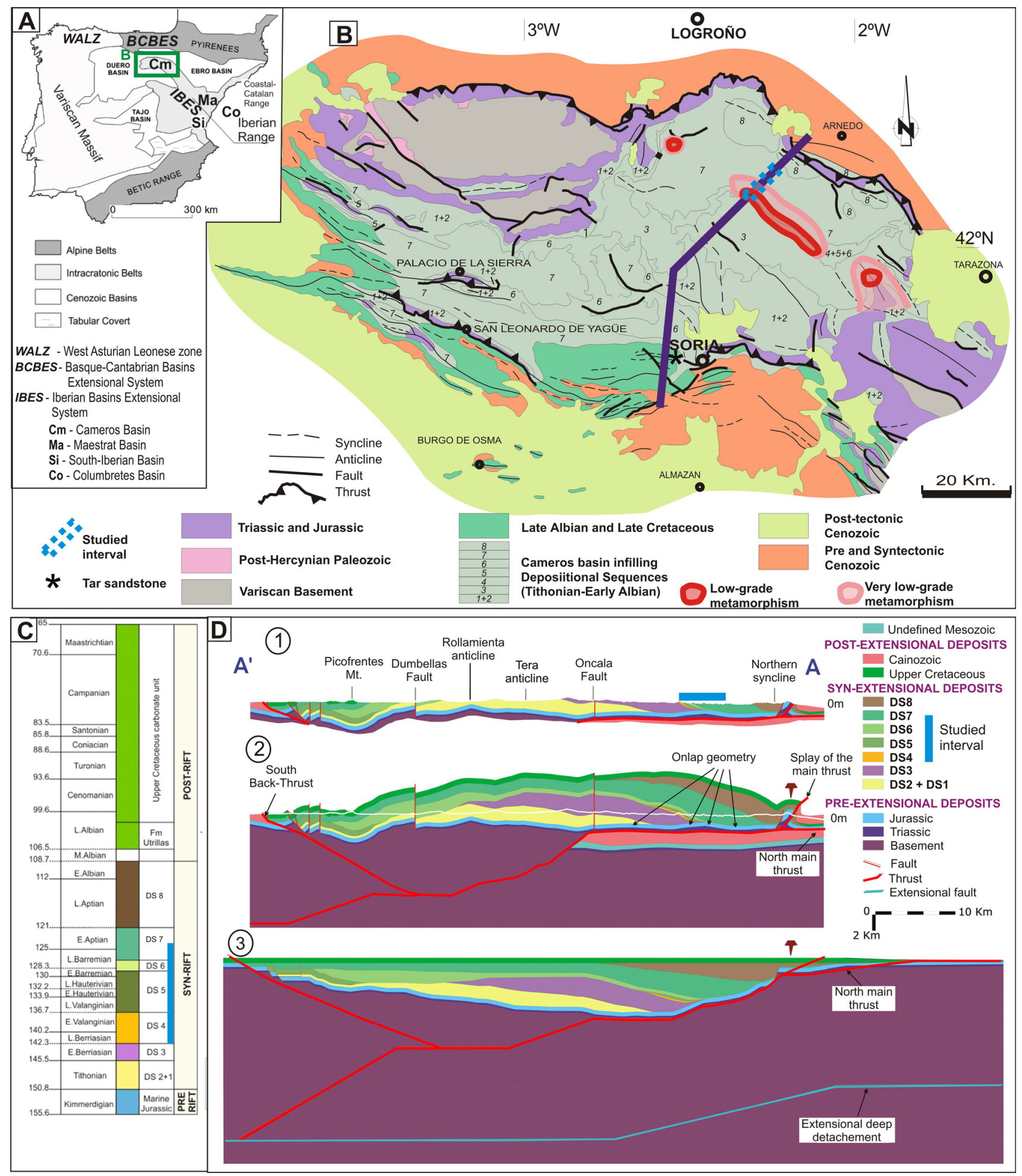

Fig. 1 a Cameros Basin in the context of the geology of the Iberian Peninsula. Modified from Mas et al. (2004). b Schematic geological map of the Cameros Basin indicating the position of the studied area, the areas affected by the hydrothermal metamorphism and the position of the cross section of Fig. 1d. Modified from Mas et al. (2003). c West Cameros Basin chronostratigraphy with indication of the studied interval. Modified from Omodeo-Salé et al. 2017. d 1. Cross section of the Cameros Basin with the present topographical profile.
2. Balanced geological cross section with the reconstruction of the eroded part and of the deeper part. The onlap geometry of the depositional sequences (DS) onto the underlying Jurassic substratum is indicated. 3. Restoration of the cross section to the undeformed state previous to the Alpine contraction and to the deposition of the postrift Upper Cretaceous unit. Figs. D1, D2 and D3 are modified from Omodeo-Salé et al. (2014) 
Fig. 2 Section of the Urbion Group in Yanguas section showing the position of the samples, synthesized from Ochoa (2006). DS-7 is in an open rectangle because it is only partially drawn (it is $1700 \mathrm{~m}$-thick, only the first $580 \mathrm{~m}$ are drawn here). Colors of the veins correspond to colors of the histograms of Fig. 8. The black arrow points a particularly thick clay interval (see explanation in the text)
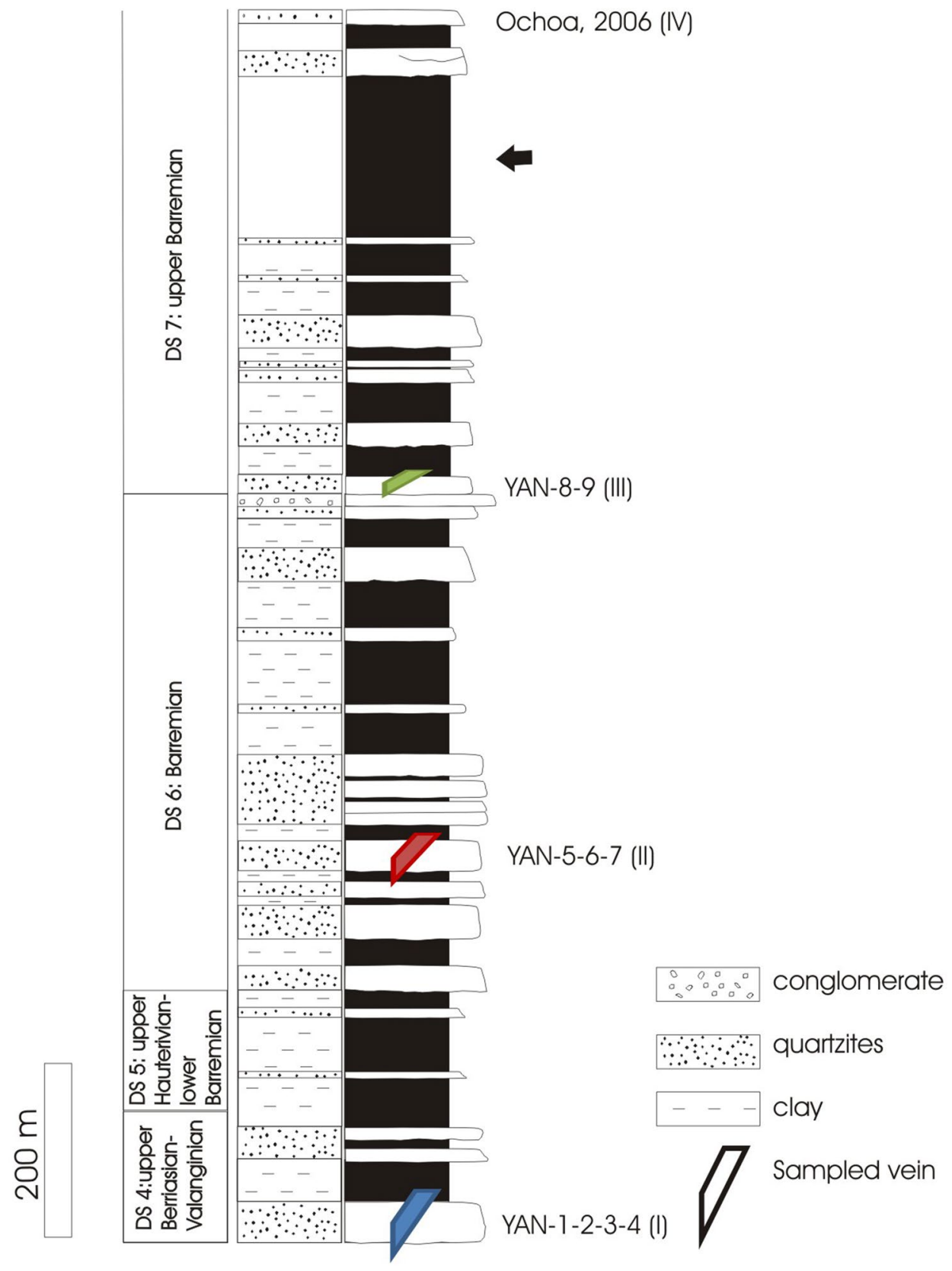

Fig. 3 Field photograph of quartz veins and indications of the types of sample: a Sample in the boundary of the host rock and the vein. b Sample oriented to the host rock. Arrow was drawn to indicate the position of the sample in relation to the host rock

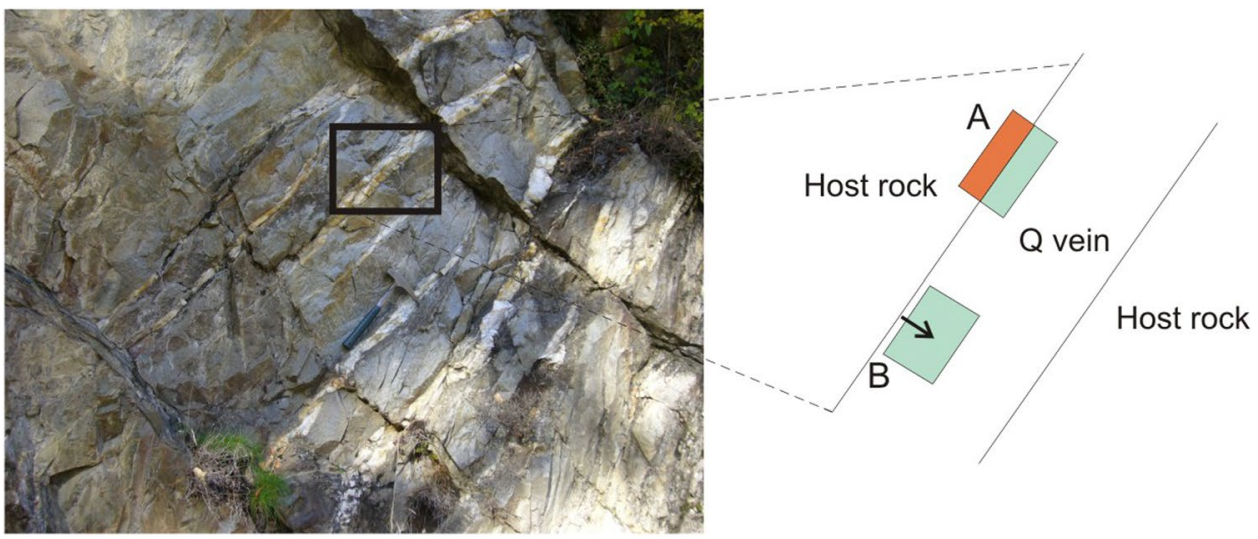


horizontal extensional fault located several kilometers deep (Fig. 1d; Mas et al., 1993, 2003, 2019; Guimerà et al., 1995; Omodeo-Salè et al., 2014). An alternative basin model is suggested by Guiraud and Seguret (1985), Casas-Sainz and Gil-Imaz, (1998), Mata et al., (2001), Villalaín et al., (2003) and Casas-Sainz et al., (2009). They proposed the formation of the basin as a consequence of a normal listric fault. Discussion of both models can be found in Casas-Sainz et al., (2012), González-Acebrón et al., (2012), Omodeo-Salé et al., (2014) and references therein.

The Cameros Basin was inverted during the Cenozoic Alpine orogeny, when the sedimentary fill was uplifted and partially eroded (Guimerà et al., 1995; Mas et al., 1993; Salas et al., 2001).

\subsection{Basin infill}

The sedimentary infill of the Cameros Basin has been divided into eight depositional sequences (DS, Mas et al., 2002, 2003, 2019) (Figs. 1c, d). The Urbion Group shows a thickness of $2560 \mathrm{~m}$ in the study area (Ochoa, 2006), which corresponds to the depocenter area for this Group (Yanguas section, Figs. 1b, d). It is composed of four depositional sequences (DS-4 to 7, Figs. 1d and 2), from late Berriasian to early Aptian in age (Mas et al., 2002, 2004, 2011), mainly deposited in broad braided and meandering fluvial systems (Mas et al., 2002; Ochoa, 2006).

Both host rocks and veins within them have experienced a burial depth close to $4950 \mathrm{~m}$ for the bottom of the Urbion Group (position I, Table 1, Fig. 2) to $3510 \mathrm{~m}$ (position IV, Table 1, Fig. 2). These calculations are based on Fig. 4 in Omodeo-Salé et al. (2017) and the Yanguas section from Ochoa (2006).

The Urbion Group in the Yanguas section is mainly composed of quartzites, which were initially quartzarenites with a rigid framework that provides an initial high porosity (40\%, Annex 2 in Ochoa, 2006). The porosity reduction of the quartzarenites occurred mainly by mechanical compaction during burial (ICOMPACT $=0.70-0.96$, Annex 2 in Ochoa, 2006).

Sedimentological and petrological evidence has suggested that a petroleum system was activated during the evolution of the Cameros Basin (Mas et al., 2002, 2003, 2019; Omodeo-Salé et al., 2019). Solid hydrocarbon remains predating quartz syntaxial overgrowths in the sandstones of the Urbión Group have been found (Ochoa, 2006; Ochoa et al., 2007), testifying to the migration of hydrocarbons through these deposits during a relatively early diagenetic stage. The lower Albian tar sandtones outcropping in the southern part of the basin (asterisk in Fig. 1; Mas et al., 2003; Omodeo-Salé et al., 2019) are another indication of the hydrocarbon migration.

\subsection{Metamorphic processes}

During the Late Albian to Coniacian, hydrothermal alteration affected the deposits of the Eastern sector of the Cameros Basin (Fig. 1b; Casquet et al., 1992). The main features of this thermal alteration are: (1) metamorphic grade is controlled by rock composition and permeability rather than by burial depth (Alonso-Azcárate et al., 1995; Barrenechea et al., 1995, 2000, 2001; OmodeoSalé et al., 2017); (2) thermal inversions across sections in the depocenter, for example a single stratigraphic section Valanginian-Barremian deposits of the Urbion Group, exhibits a higher metamorphic grade than the Tithonian and Berriasian deposits of Tera and Oncala older groups (Barrenechea et al., 2001; Mantilla-Figueroa et al., 1998, 2002); (3) post-rift age of alteration (Late Albian to Coniacian, $107 \pm 5$ to $85 \pm 6$ Ma with $\mathrm{K}-\mathrm{Ar}$ on authigenic illites of the bottom part of the Urbión Group, Casquet et al., 1992), after the maximum burial stage, reached during the Early Albian (Mas et al., 2002, 2003); (4) metamorphic conditions from very low to low-grade, with maximum temperature and pressure of $326 \pm 13{ }^{\circ} \mathrm{C}$ and $1 \mathrm{kbar}$ at the metamorphic peak (based on chorite composition, Casquet et al., 1992), pointing to fluids coming originally from at least $11 \mathrm{~km}$ depth (Mantilla-Figueroa et al., 2002); and (5) the presence of centimeter-sized pyrite crystals in lutites formed by metamorphic sulphidation of chlorite close to the metamorphic peak. The $\delta^{34} \mathrm{~S}$ in the pyrite and its anhydrite inclusions provided values of near $370{ }^{\circ} \mathrm{C}$ (AlonsoAzcárate et al., 1999a, 1999b).

Finally, the paragenesis at the bottom part of the Urbión Group is formed by quartz + illite + chlorite + chloritoid \pm pyrophyllite ( \pm muscovite \pm carbonate) according to Casquet et al. (1992), and quartz + chlorite + muscovite + paragonite + chloritoid \pm calcite \pm albite according to Mata et al. (2001). Casquet et al. (1992) considered the metamorphism as related to the deformation, whereas Casas-Sainz and Gil-Imaz (1998) and Mata et al. (2001) proposed that the metamorphic peak postdated the cleavage-related folding.

\subsection{Previous studies on fluid inclusions in the Urbión Group}

Mantilla-Figueroa (1999) studied the hydrothermal metamorphism of the basin, analysing the veins that cross-cut the deposits of the different depositional sequences. This author interpreted the quartz veins in the Urbion Group as antitaxial (cement growing towards the walls of the vein) and formed by a crack-seal mechanism, containing primary aqueouscarbonic inclusions. Microthermometry and Raman spectroscopy indicated a $\mathrm{H}_{2} \mathrm{O}+\mathrm{NaCl}+\mathrm{CO}_{2}$ system (Table 31 in 


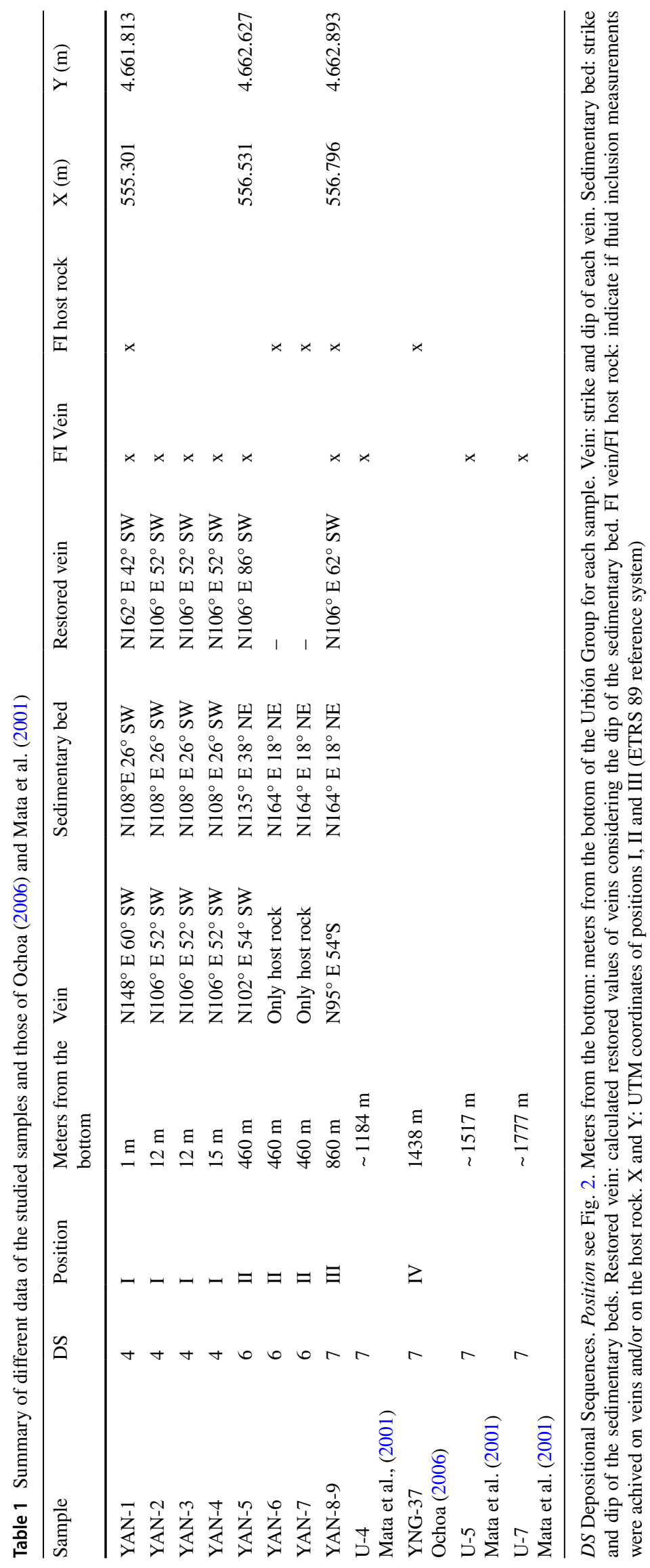


Fig. 4 Photomicrographs (parallel nicholls and SEM-CL) of the host rock. a Quartz syntaxial overgrowth in the host rock. Notice that this particular quartz grain is very rich in fluid inclusions and this fact enhaces the distintion between the detrital grain and the overgrowth. b Detail of previous photograph showing the biphasic fluid inclusions (encircled) in the quartz syntaxial overgrowth. YAN-1. c, d Non-luminescent quartz overgrowth (yellow arrow) under parallel nicholls and SEM-CL. The $T_{\mathrm{h}}$ of a fluid inclusion (FI) in this cement is $170.0-175.7^{\circ} \mathrm{C}$ (diagenetic temperature). The overgrowth below presents some areas with slightly brighter luminescence (orange arrow). YAN-1. e, $\mathbf{f}$ Quartz filled microfracture (arrows) crossing the detrital grain revealed under SEMCL (f), non-observable under conventional microscopy (e). YAN-7
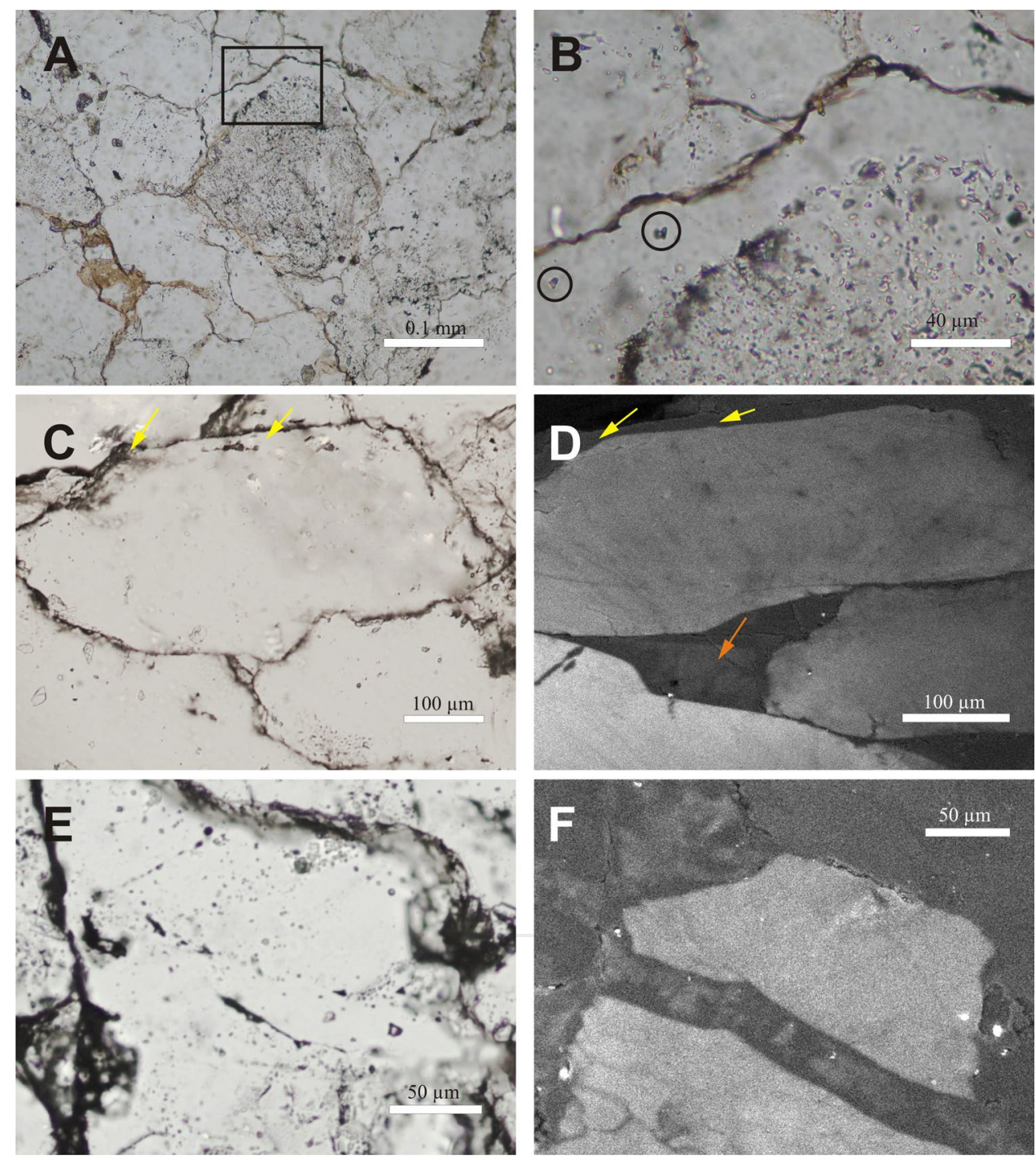

Mantilla-Figueroa, 1999). Mata et al. (2001) characterized the fluid inclusions of the veins of the Urbion Group by the system $\mathrm{NaCl} \pm \mathrm{CO}_{2}\left(+\mathrm{N}_{2}\right) \pm \mathrm{H}_{2} \mathrm{O}$, indicating a $T_{\mathrm{h}}$ decrease from bottom to top of the Urbión Group (Table 1 in Mata et al., 2001). Scarce $\mathrm{N}_{2}$ was detected by Raman spectroscopy in fluid inclusions of the bottom part of the Urbión Group in Yanguas $\left(\mathrm{CO}_{2}: \mathrm{N}_{2}\right.$ from 1:0 to 1: 0.25, Mata et al., 2001).

Ochoa (2006) and Ochoa et al. (2007) studied the microthermometry of primary fluid inclusions in several stratigraphic sections of the eastern sector of the Cameros Basin. These authors combined fluid inclusion data with SEM-CL observations, interpreting two quartz cementation stages, one diagenetic (homogenization temperatures, $T_{\mathrm{h}}$ : $\left.110-115^{\circ} \mathrm{C}\right)$ and another hydrothermal $\left(T_{\mathrm{h}}: 95^{\circ}-227^{\circ} \mathrm{C}\right)$. One sample (YNG-37) of Ochoa (2006) is located in the study area, in DS 7. The microthermometric results of this sample are compiled in Table 2, as well as the data available from previous authors for the Yanguas area.

\section{Samples and analytical methods}

The Yanguas section (Fig. 1b) was chosen because of the abundance of quartz veins and is located on road SO-315 between the towns of Yanguas (Soria) and Las Ruedas de Enciso (La Rioja). Nine outcrop samples were collected from 7 quartz veins and 3 quartzite host rocks, in three different positions of this section (I, II, III in Fig. 2). Position I is separated by $860 \mathrm{~m}$ of metamorphosed sedimentary rocks from position III (Fig. 2 and Table 1). Position IV corresponds with sample YNG-37 of Ochoa (2006) and is located $1438 \mathrm{~m}$ from the bottom of the section (Fig. 2, Tables 1 and 2 ). The strike and dip of each quartz vein was measured and restored with the strike and dip of the sedimentary beds (Table 1). Oriented samples were collected from both the host rock and veins as indicated in Fig. 3 in order to compare their behaviour to the paleofluids. Two samples (YAN-1 and 8) show the contact between the host rock and the vein (Fig. 3a). 


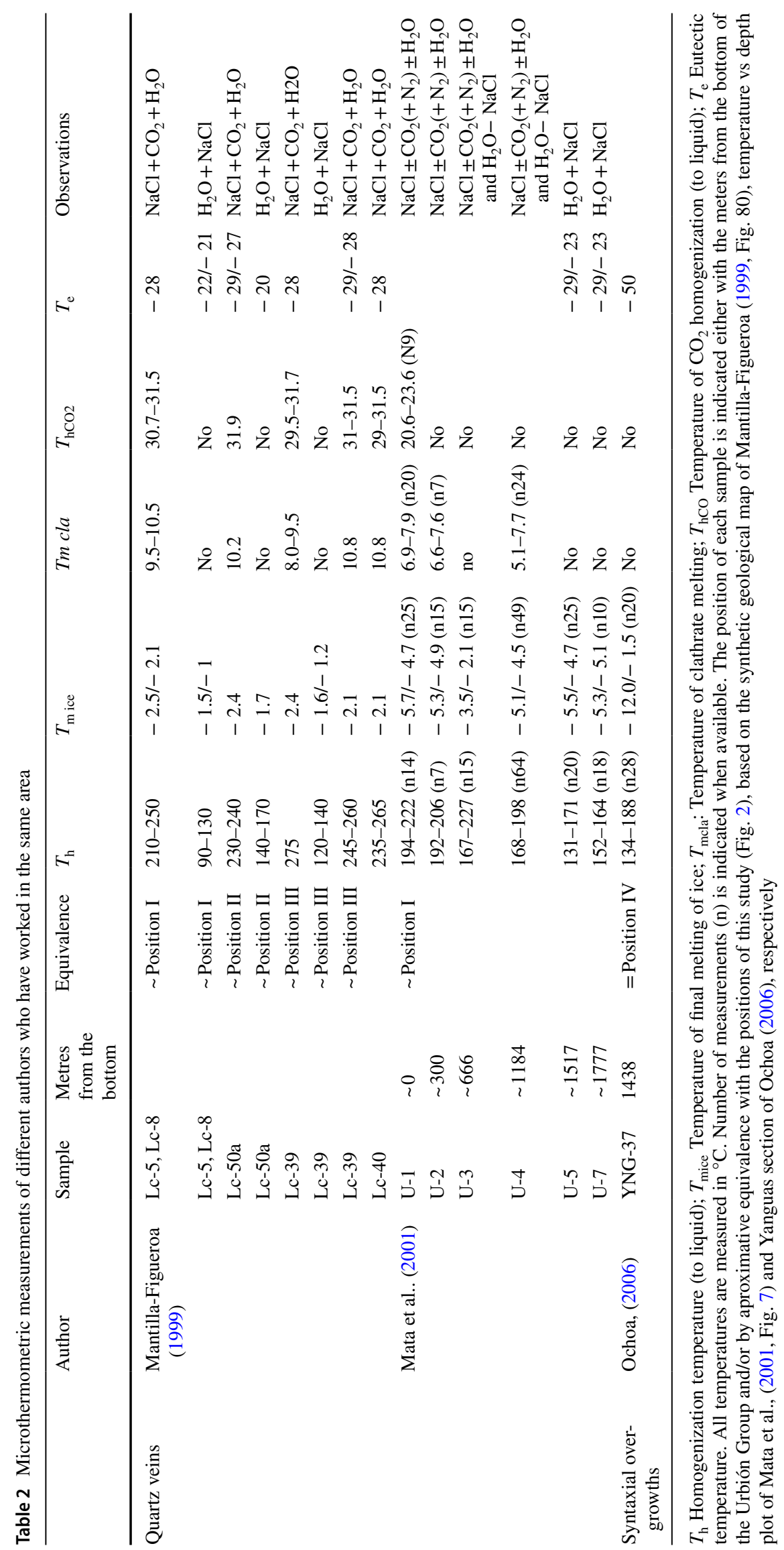


Doubly polished thick Sects. $(70-100 \mu \mathrm{m})$ were prepared for all the samples without any heating and glued to frosted glass with cyanoacrilate. After optical petrographic analysis of the sections, selected areas were cut and removed from the glass using acetone to prepare the wafers. The microthermometric study was performed using a Linkam THMSG600 heating and freezing stage. The stage was calibrated with synthetic fluid inclusions, including triple point of $\mathrm{CO}_{2}\left(-56.6{ }^{\circ} \mathrm{C}\right)$, melting point of $\mathrm{H}_{2} \mathrm{O}\left(0.0^{\circ} \mathrm{C}\right)$, and critical point of $\mathrm{H}_{2} \mathrm{O}\left(374.1{ }^{\circ} \mathrm{C}\right)$. Melting point of $\mathrm{H}_{2} \mathrm{O}$ standards show that the accuracy for low-temperature measurements are better than $\pm 0.1^{\circ} \mathrm{C}$. Critical point standards show that the accuracy for high temperature measurements are better than $\pm 1.0^{\circ} \mathrm{C}$. Water-volume fractions after clathrate melting was calculated from areas on microphotographs using the software ImageJ. Freezing was done prior to heating in the $\mathrm{CO}_{2}$ bearing inclusions, because some fluid inclusions tend to decrepitate at high temperatures. On the contrary, in the fluid inclusions which contain only liquid and vapor at room temperature (mostly in the quartz grain overgrowths) heating was performed prior to freezing, in order to avoid the possible stretching by ice formation. Clathrate melting $\left(T_{\text {mcla }}\right)$ was measured as a monitor of salinity (Diamond, 1994) and the temperature of homogenization of the $\mathrm{CO}_{2}$ phases $\left(T_{\mathrm{hCO} 2}\right)$ as a monitor of the bulk density (Diamond, 2003). The phase transition temperatures are shown in histograms and the FIAs are represented separately in box and whisker graphics. In order to interpret both types of graphics it is important to remember than the number of available fluid inclusions varies from one sample to another.

A confocal Raman instrument (BWTEK Voyage BWS435-532) coupled with a microscope (Olympus BX51) with a $50 \times$ objective and the Linkam stage was used for the analysis of selected FIAs of sample YAN-2, after freezing analysis and before heating. Spectra were recorded at $30^{\circ} \mathrm{C}$ with a laser of $532 \mathrm{~nm}$ from 100 to $3750 \mathrm{~cm}^{-1}$, with a resolution of $2 \mathrm{~cm}^{-1}$, with long adquisition times (15-60 $\mathrm{min}$ ).

SEM-CL (Scanning Electron Microscope coupled with cathodoluminescece) was performed in YAN-5 for the study of quartz veins and in YAN-1, YAN-7 and YAN-8 for the sandstone host rock. Samples were coated with carbon for examination. Two SEM-CL equipments were used: a Gatan PanaCL photomultiplier-based CL detector installed on a Leo 1550 SEM (Museo Nacional de Ciencias Naturales) and a Gatan ChromaCL2 instaled on a Jeol JSM-820 (Unidad de Técnicas Geológicas, CAI de Ciencias de la Tierra y Arqueometría, UCM). The operating conditions were $30-\mathrm{kV}$ and $20-\mathrm{kV}$ voltage, respectively.

\section{Results}

\subsection{Quartz grain overgrowths (host rock)}

The observed primary fluid inclusions in quartz grain overgrowths (Figs. $4 \mathrm{a}, \mathrm{b})$ are usually very small $(1-5 \mu \mathrm{m})$, but occasionally showing bigger sizes in well-developed overgrowths (until $18 \mu \mathrm{m}$, Table 3). They are liquid-rich at room temperature and located at the boundary between the detrital grain and the overgrowth or inside the overgrowth (Fig. 4b). Under SEM-CL, the overgrowths are commonly a homogeneous non-luminescent rim (around $10 \mu \mathrm{m}$-thick), postdated in some cases by a brighter and thicker luminescent cement (Fig. 4c, d). This brighter phase also appears in quartz filled microfractures (around $30 \mu \mathrm{m}$-thick) crossing the detrital grains, showing irregular luminescent patches (Fig. 4e, f).

Final melting of ice ( $\left.T_{\text {mice }}\right)$ could be only recorded in position I and II, and display variable values from $-12.4{ }^{\circ} \mathrm{C}$ to $-1.6{ }^{\circ} \mathrm{C}$ (Table 3), with the most negative values characteristic of position II (Fig. 5a). Where it has been possible to observe the first melting (eutectic temperature, $T_{\mathrm{e}}$ ), the recorded temperatures are between $-31{ }^{\circ} \mathrm{C}$ to $-25{ }^{\circ} \mathrm{C}$ (Table 3). Clathrate melting ( $\left.T_{\text {mcla }}\right)$ was only observed in a couple of cases in position I, with temperatures between 6.0 and $6.5^{\circ} \mathrm{C}$ (Table 3). Homogenization is to the liquid phase in a range from $124^{\circ} \mathrm{C}$ to $265^{\circ} \mathrm{C}\left(T_{\mathrm{h}}\right.$, Fig. $5 \mathrm{~b}$ and Table 3$)$. Very large $T_{\mathrm{h}}$ variation within individual FIAs is observed in positions I to III (from $13^{\circ} \mathrm{C}$ to more than $100^{\circ} \mathrm{C}$, Fig. $5 \mathrm{c}$ ), and only occasionally decreasing $T_{\mathrm{h}}$ values from the boundary between the quartz grain and the cement towards the outer part of it (YAN-6, FIA 8, Table 3). The FIAs of position IV (YNG-37, Ochoa, 2006) show a narrower range in $T_{\mathrm{h}}$ from $16{ }^{\circ} \mathrm{C}$ to $25^{\circ} \mathrm{C}$ within individual FIAs (Fig. 5c).

\subsection{Quartz veins}

Restored strikes of the veins are between $\mathrm{N} 106^{\circ}$ to $162^{\circ} \mathrm{E}$, and dips from $42^{\circ}$ to $86^{\circ} \mathrm{SW}$ (Table 1). These veins are filled with milky quartz and occasionally some chlorite with no remaining porosity. They are $1-30 \mathrm{~cm}$ wide and typically cut the whole strata perpendicular to the stratification (Fig. 3). Fibrous quartz sometimes fills thinner fractures $(\sim 5 \mathrm{~cm})$, with fibres perpendicular to fracture walls. The amount of quartz veins lessens towards the top of the section.

The fluid inclusion study was focused on the milky quartz veins. Under the microscope the veins are formed by crystals usually elongated perpendicular to the walls, $0.1-4 \mathrm{~cm}$-long and with a length to width ratio between $5: 1$ to 5:3. They present sweeping extinction and sharp boundaries between crystals, sometimes serrated in the wide direction. Smaller crystals $(<0.1 \mathrm{~mm})$ are observed between the main crystals following the length direction. 
Table 3 Microthermometric values of FIAs in quartz grain overgrowths (host rock)

\begin{tabular}{|c|c|c|c|c|c|c|c|c|c|}
\hline Position & Sample & FIA & IF & Size & $T_{\mathrm{h}}$ & $T_{\text {mice }}$ & Salinity & $T_{\mathrm{m} \text { cla }}$ & $T_{\mathrm{e}}$ \\
\hline \multirow[t]{12}{*}{ I } & \multirow[t]{11}{*}{ YAN-1 } & 1 & 1 & 8 & $235.0-237.5$ & $-8.6 /-8.3$ & N.P & 6.3 & -31 \\
\hline & & 1 & 2 & 6 & $180.0-189.0$ & & & & \\
\hline & & 2 & 3 & 2 & $>269.0$ & & & & \\
\hline & & 2 & 4 & 3 & $>291.0$ & & & & \\
\hline & & 3 & 5 & 3 & $228.0-232.8$ & & & & \\
\hline & & 3 & 6 & 10 & $226.0-230.0$ & $-6.0 /-5.5$ & 6.4 & $6.0-6.5$ & \\
\hline & & 3 & 7 & 2 & $163.4-170.1$ & -6.1 & 9.3 & & \\
\hline & & 4 & 8 & 4 & 194.0-195.4 & $-3.3 /-3.1$ & $5.1-5.4$ & & \\
\hline & & 5 & 9 & 5 & 193.0-200.1 & & & & \\
\hline & & 6 & 10 & 8 & $170.0-175.7$ & & & & \\
\hline & & 7 & 11 & 5 & $213.0-218.0$ & & & & \\
\hline & Range & & & & $163.4-237.5$ & $-8.6 /-3.1$ & $5.1-9.3$ & $6.0-6.5$ & -31 \\
\hline \multirow[t]{14}{*}{ II } & \multirow[t]{8}{*}{ YAN-6 } & 8 & 1 & 18 & $263.0-265.0$ & $-2.7 /-2.5$ & $4.2-4.5$ & & -25 \\
\hline & & 8 & 2 & 3 & $200.0-207.0$ & & & & \\
\hline & & 8 & 3 & 2 & $168.0-178.0$ & & & & \\
\hline & & 9 & 4 & 8 & $220.0-225.0$ & & & & \\
\hline & & 10 & 5 & 8 & $129.0-134.0$ & $-12.4 /-11.9$ & $15.9-16.3$ & & \\
\hline & & 10 & 6 & 6 & $140.0-150.0$ & $-9.1 /-8.2$ & $11.9-12.9$ & & \\
\hline & & 11 & 7 & 8 & $161.8-164.0$ & $-10.2 /-10$ & $13.9-14.2$ & & \\
\hline & & 12 & 8 & 5 & $154.0-159.7$ & & & & \\
\hline & \multirow[t]{5}{*}{ YAN-7 } & 13 & 1 & 5 & $132.0-136.0$ & $-1.8 /-1.6$ & $2.7-3.1$ & & -25 \\
\hline & & 14 & 2 & 2 & $132.0-136.2$ & & & & \\
\hline & & 15 & 3 & 4 & $136.0-140.0$ & & & & \\
\hline & & 16 & 4 & 8 & $137.0-140.5$ & $-11.0 /-10.8$ & $14.8-15.0$ & & -30 \\
\hline & & 17 & 5 & 14 & $145.0-150.4$ & $-11.0 /-10.8$ & $14.8-15.0$ & & \\
\hline & Range & & & & $129.0-265.0$ & $-12.4 /-1.6$ & $2.7-16.3$ & & $-30 /-25$ \\
\hline \multirow[t]{11}{*}{ III } & \multirow[t]{10}{*}{ YAN-8 } & 18 & 1 & 4 & $124.0-133.6$ & & & & \\
\hline & & 18 & 2 & 5 & $170.5-181.0$ & & & & \\
\hline & & 18 & 3 & 3 & $170.0-180.0$ & & & & \\
\hline & & 18 & 4 & 4 & $195.0-203.0$ & & & & \\
\hline & & 18 & 5 & 5 & 196.0-203.3 & & & & \\
\hline & & 19 & 6 & 2 & $140.0-148.0$ & & & & \\
\hline & & 19 & 7 & 5 & $154.0-156.0$ & & & & \\
\hline & & 19 & 8 & 4 & $>245.0$ & & & & \\
\hline & & 20 & 9 & 4 & $130.0-142.0$ & & & & \\
\hline & & 20 & 10 & 4 & $>245.0$ & & & & \\
\hline & Range & & & & $124.0-203.3$ & & & & \\
\hline
\end{tabular}

Position: see Fig. 2

FIA Fluid Inclusion Assemblage. FI Fluid Inclusion; $T_{\mathrm{h}}$ : Homogenization temperature (to liquid). In very small fluid inclusions, the $T_{\mathrm{h}}$ was difficult to determine even with cycling. In these cases the $T_{\mathrm{h}}$ are indicated as a minimum temperature (e.g. $>269.0^{\circ} \mathrm{C}$ ). $T_{\text {mice }}$ Temperature of final melting of ice. $T_{\text {mcla }}$ Temperature of clathrate melting. $T_{\mathrm{e}}$ Eutectic temperature. All temperatures are measured in ${ }^{\circ} \mathrm{C}$ and salinities in mass \% NaCl-eq, calculated based on Bodnar (1993) equation, or using Steele-MacInnis (2008) program (when $T_{\mathrm{mcla}}, T_{\text {mice }}$ and $T_{\mathrm{h}}$ are available). N.P. No possible calculation with measured value
The milky quartz veins display a crack-sealing texture determined by SEM-CL (Fig. 6) pointing to multiple fracture and sealing events. This texture is sometimes also recognizable under conventional microscopy: some areas show cloudier appearance, are richer in fluid inclusions and are cut by a younger and cleaner quartz, poorer in fluid inclusions (Fig. 6a1). The clearer quartz is non-luminiscent (Figs. 6a1, a2) and the cloudy one shows bright luminescence (Figs. 6a3, b1, b2 and b3) under SEM-CL. Thin incremental fractures $(\sim 20 \mu \mathrm{m})$ filled by non-luminescent quartz (arrows in Fig. 6a3) crosscut both the bright luminescent and 


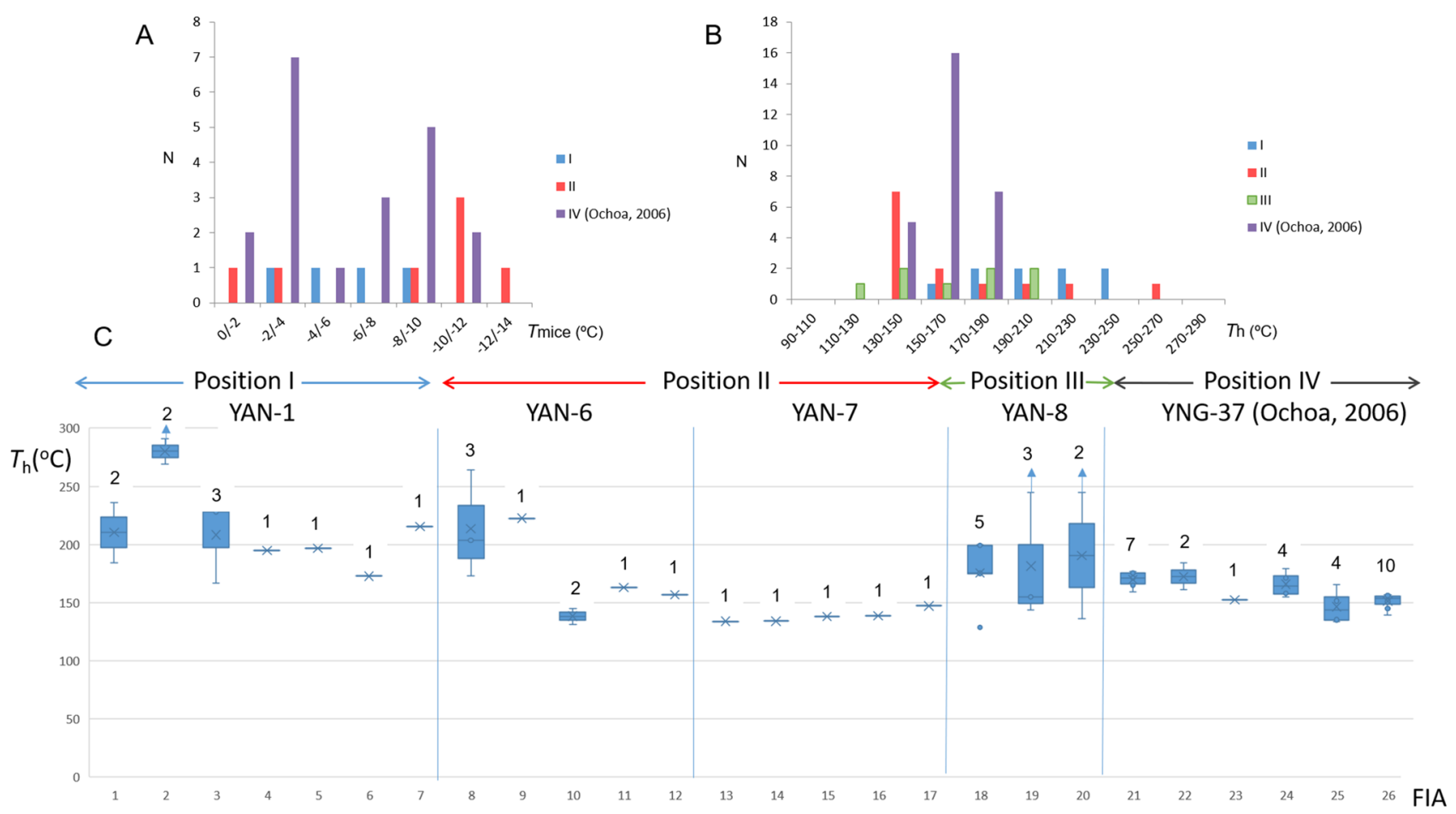

Fig. 5 Fluid inclusion graphics of the host rock: $\mathbf{a}$, b histogram of $T_{\text {mice }}\left({ }^{\circ} \mathrm{C}\right)$ and $T_{\mathrm{h}}\left({ }^{\circ} \mathrm{C}\right)$. I, II, III and IV are the position of the samples (see Fig. 2). There are no data for $T_{\text {mice }}$ for position III due to the small size of the fluid inclusions. Notice that $T_{\mathrm{h}}$ are lower in the stratigraphic highest samples (positions III and IV) c Box and whisker graphic of $T_{\mathrm{h}}\left({ }^{\circ} \mathrm{C}\right)$. The $\mathrm{x}$ axis represents the FIA number (see Table 3) and the number on the right side of each box is the

the non-luminescent quartz, showing different orientations (Fig. 6a3, b2).

FIAs of the older quartz form cloudy clusters, or sometimes intra-crystal trails which are approximately perpendicular to the vein-host rock contact. FIAs of the younger quartz form intra-crystal trails which are perpendicular to the boundary of the older quartz (Fig. 7a). Fluid inclusions hosted in both older and newer quartz generally show similar petrographic characteristics. The quartz veins present fluid inclusions containing both liquid and vapor $\mathrm{CO}_{2}$ and an aqueous liquid phase at room temperature (Fig. 7b). Their sizes range from 3 to $52 \mu \mathrm{m}$ (generally between 10 and $20 \mu \mathrm{m}$, Table 4). The aqueous liquid phase usually represents $90-95 \%$ of the total fluid inclusion. Sometimes the $\mathrm{CO}_{2}$ liquid phase is so scarce that it is indistinguible from the $\mathrm{CO}_{2}$ vapor phase (Fig. 7c). Some fluid inclusions are very irregular showing re-entrants of the host quartz (Figs. 7c-f), in optical continuity with the surrounding quartz. Less commonly, some FIAs in the cloudier quartz are formed by negative crystal shape inclusions (Figs. $7 \mathrm{~g}, \mathrm{~h}$ ).

As far as the multiple sealing events are only clearly recognizable under SEM-CL, indication of the fracturation number of fluid inclusions in a particular FIA. The up-arrows in FIAs 2, 19 and 20 are because of very small fluid inclusions, in which the $T_{\mathrm{h}}$ was difficult to determine even with cycling. In these cases they are indicated as a minimum temperature (e.g. $>269.0{ }^{\circ} \mathrm{C}$, Table 3). Notice the large variation in the $T_{\mathrm{h}}$ range in each FIA with the exception of Position IV. I, II and III are the position of the samples and their colors correspond to Fig. 2

stages was not possible during microthermometry. Examination of the fluid inclusions under SEM-CL after microtermometry was only performed in some quartz grain overgrowths. In the case of the veins it has been discarded due to the small size of the wafers in relation to the vein size, so petrographic relationships are lost or very difficult to establish. It is important to clarify that for microthermometry small wafers are required $\left(\sim 2 \mathrm{~mm}^{2}\right)$.

Petrographically paired vapor-rich and vapor-poor inclusions resulting from necking down after a phase change were occasionally observed and avoided for microthermometry. All microthermometric data are compiled in the Supplementary material and summarized in Table 4.

Where it has been possible to measure the $T_{\mathrm{e}}$, the obtained temperatures are around $-21{ }^{\circ} \mathrm{C}$. Further, a melting event occurs at $-56.6{ }^{\circ} \mathrm{C}$. Some FIAs in position I show this melting process at slighltly lower temperatures (down to $-57.7^{\circ} \mathrm{C}$, Table 4 ).

The clathrates melt in the presence of both liquid and vapor $\mathrm{CO}_{2} . T_{\text {mcla }}$ ranges from 7.8 to $9.7^{\circ} \mathrm{C}$ with the highest temperatures at the bottom part of the record (Fig. 8a, Table 4). Homogenization of the $\mathrm{CO}_{2}$ liquid and the $\mathrm{CO}_{2}$ 
Fig. 6 Photomicrographs of the quartz veins (YAN-05). Yellow lines allow comparison between parallel nicol photographs (A1 and B3) and SEM-CL photographs (A2, A3, B1 and B2), connecting corresponding points. All scale bars represent $0.2 \mathrm{~mm}$. a Quartz vein shows a cloudy appearance due to the abundance of fluid inclusions, with the exception of a later vein with clean appearance (arrow in A1), very poor in fluid inclusions and non-luminescent under SEM-CL (A2). Also, incremental fractures (arrows in A3) are perpendicular to the clean apperarance vein (arrow in A1). Notice that A2 and A3 pictures match in their shared corner. b Initial cementation is represented by bright luminescent quartz (B1, B2). Its growth direction is indicated by a yellow arrow in B3. Later incremental fractures are filled by non-luminescent quartz (B1, B2), some of them opening perpendicular (orange arrows in B1) to the initial growing direction. Other ones present different directions (white arrows in B2)
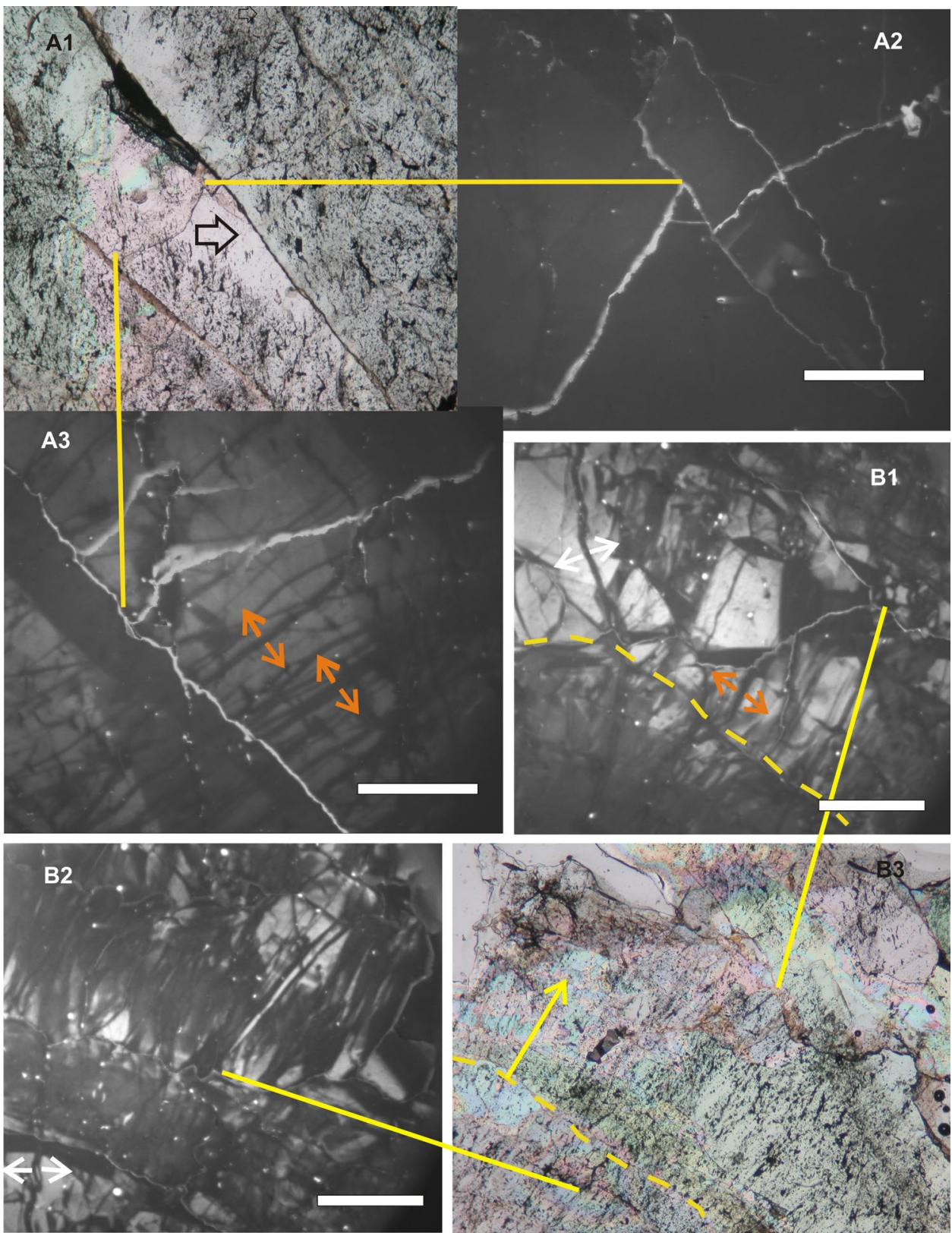



gas $\left(T_{\mathrm{hCO} 2}\right)$ to the liquid occurs between 21.1 and $31.0^{\circ} \mathrm{C}$, with the lowest values in the deepest samples and viceversa (Fig. 8b, Table 4). Fluid inclusions homogenize to the liquid in a range between $109{ }^{\circ} \mathrm{C}$ and $282{ }^{\circ} \mathrm{C}\left(T_{\mathrm{h}}\right.$, Fig. $8 \mathrm{C}$, Table 4). $T_{\mathrm{h}}$ lower than $130^{\circ} \mathrm{C}$ were only recorded in the deepest part (position I, Fig. 8c) and the minimum $T_{\mathrm{h}}$ values of each position are higher towards the top of the section (from I to III, Fig. 8c). In addition, modal values in position III (190-210 ${ }^{\circ} \mathrm{C}$ ) are higher than in position I and II $\left(150-160^{\circ} \mathrm{C}\right)($ Fig. $8 \mathrm{c})$. Most of the FIAs in positions I and II show ranges in $T_{\mathrm{h}}$ of individual FIAs that extend to several tens of degrees or more (up to $84{ }^{\circ} \mathrm{C}$, Fig. 9, Supplementary material), but some FIAs show relatively narrow ranges (see for examples FIAs 19, 23, 38 and 39, Fig. 9, Supplementary material). Position III is characterized by narrow ranges in $T_{\mathrm{h}}$ within individual FIAs (variations up to $10^{\circ} \mathrm{C}$, Fig. 9, Supplementary material). Some fluid inclusions decrepitate before reaching the homogenization, usually at temperatures above $210^{\circ} \mathrm{C}$ (Table 4 and Supplementary material).

Finally, Raman spectra have detected two broad bands around 1355 and $1580 \mathrm{~cm}^{-1}$ in some FIAs in position I (Fig. 10, sample YAN-2). No other gases than $\mathrm{CO}_{2}$ have been detected. 



Fig. 7 Photomicrographs (parallel nicols) of fluid inclusions in quartz veins. a Cleaner quartz poorer in fluid inclusions (bottom, left), after a cloudier quartz richer in fluid inclusions. Notice FIA in cleaner quartz (encircled) are approximately perpendicular to the boundary of the cloudier quartz phase. YAN-5. b FIA containing fluid inclusions containing $\mathrm{CO}_{2}$ gas, $\mathrm{CO}_{2}$ liquid and $\mathrm{H}_{2} \mathrm{O}+\mathrm{NaCl}$ at room tempera-

\section{Discussion}

Restored strikes and dips of the veins $\left(\mathrm{N} 106^{\circ}\right.$ to $162^{\circ} \mathrm{E}, 42^{\circ}$ to $86^{\circ} \mathrm{SW}$, Table 1 ) are approximately perpendicular to the main extensional directions of the basin, which are $\mathrm{N}-\mathrm{S}$ (e.g: Mas et al., 2011) and NE-SW (García-Lasanta et al., 2014; Guiraud \& Seguret, 1985), and to the extensional directions of the Iberian-European plate boundary for the mid Cretaceous (NNE-SSW, see Figs. 2b, c in Tugend et al., 2014).

The lack of remaining porosity of these veins is typical of fractures formed in metamorphic and hydrothermal environments vs. fractures cemented during diagenesis, which are typically open and scarcely cementated in clastic sediments (Becker et al., 2010). The material in the host rock (quartzarenite) was a favourable substrate for quartz cementation. This "substrate effect" has been documented by Laubach et al. (2004): "for same fracture and burial history, small fractures in lithic and feldspatic sandstone are less completely filled than those in more quartzose

ture. YAN-2. c FIA of irregular shaped fluid inclusions. YAN-5. d- f Irregular fluid inclusions showing quartz re-entrants. All inclusions are 12-14 $\mu \mathrm{m}$-long. YAN-2, YAN-5, YAN-9, respectively. g Negative crystal shape carbonic fluid inclusion, $20 \mu \mathrm{m}-$ long. YAN-5. h FIA of negative crystal shape carbonic fluid inclusions. YAN-5

sandstone". SEM-CL images have demonstrated a complex growth pattern (Fig. 6). Although the growth of the fractures in field observations can be described as antitaxial (Mantilla-Figueroa, 1999), under the SEM-CL several fracturing stages with no consistent grow direction are observed (ataxial growth).

\subsection{Quartz grain overgrowths (host rock)}

The eutectic temperatures are around the metastable eutectic of $\mathrm{H}_{2} \mathrm{O}-\mathrm{NaCl}\left(-28^{\circ} \mathrm{C}\right.$, Davis et al., 1990), so this compositional model has been applied for salinity calculations. Salinities are between 2.7-16.3 mass \% ( $\mathrm{NaCl}$ eq.) (Table 3). They have been calculated using in most cases by the Bodnar Eq. (1993). When clathrate melting has been observed the program of Steele-MacInnis (2008) has been applied (Table 3). Regarding position IV (sample from Ochoa, 2006), the lower eutectic temperatures $\left(-50{ }^{\circ} \mathrm{C}\right.$, Table 2$)$ are related to the presence of divalent cations in the fluid 







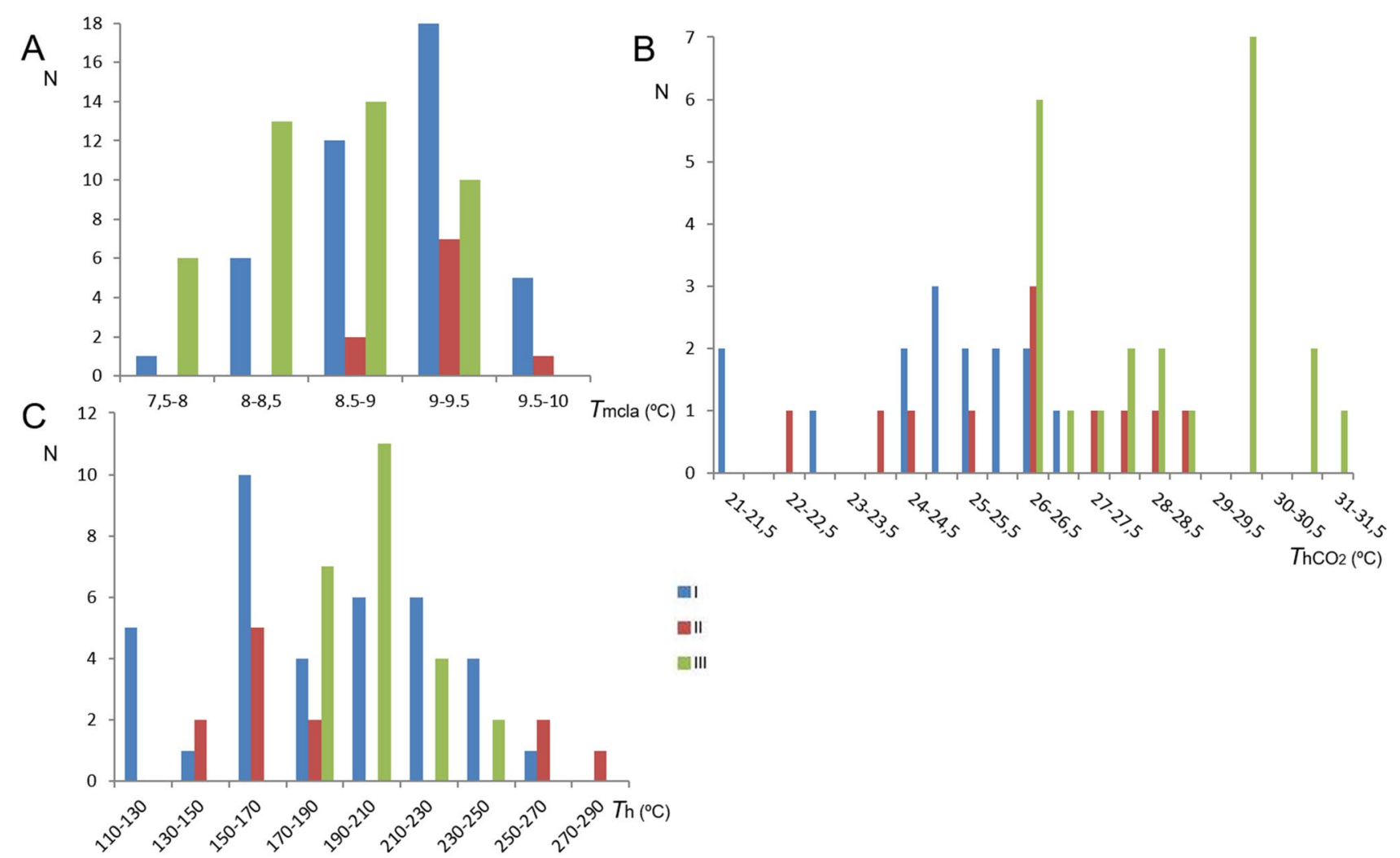

Fig. 8 Histograms for fluid inclusion data of the quartz veins. a $T_{\text {mcla }}$ $\left({ }^{\circ} \mathrm{C}\right)$. b $T_{\mathrm{hCO}_{2}}\left({ }^{\circ} \mathrm{C}\right)$. Notice that $T_{\mathrm{hCO} 2}$ increase to the top. c $T_{\mathrm{h}}\left({ }^{\circ} \mathrm{C}\right)$. Notice that minimum $T_{\mathrm{h}}$ values are higher to the top of the section.

inclusions of this sample (Ochoa, 2006). This fact points to some evolution of the hydrothermal fluids from the bottom to the top of the section, with enrichment of $\mathrm{Ca}^{2+}$ and/or $\mathrm{Mg}^{2+}$, probably due to the leaching of the underlying clayrich strata (black arrow in Fig. 2).

The non-luminiscent overgrowth (Fig. 4c,d) is interpreted as diagenetic (Zinkernagen, 1978) and the brighter one that also appears filling microfractures crossing the grains as hydrothermal (Fig. 4c-f). These two generations of cements (non-observable under conventional microscopy) justify the very large $T_{\mathrm{h}}$ variation within individual FIAs observed in positions I to III (Fig. 5c). Reequilibration of the FI due to the successive hydrothermal pulses could have also played an important role.

Maximum $T_{\mathrm{h}}$ values generally decrease to the top of the section (Figs. $5 \mathrm{~b}$ and 10), especially considering position IV. The narrow range of $T_{\mathrm{h}}$ within individual FIAs in Position IV (Fig. 5c) is probably due to less reequilibration of fluid inclusions in this position. This implies a lower hydrothermal affect in the upper part of the Urbión Group. In fact, quartz veins are much more common in the lower part of the Urbión Group. The presence of $180 \mathrm{~m}$ of clay-rich strata without any interlayered sandstone below position IV (black
Further, maximum values tend to decrease from position II- III. I, II and III are the position of the samples and their colors correspond to Figs. 2 and 5

arrow in Fig. 2) could have limited the circulation of the hydrothermal fluids towards this position.

\subsection{Quartz veins}

The $T_{\mathrm{e}}$ of fluid inclusions are around the eutectic of the $\mathrm{H}_{2} \mathrm{O}-\mathrm{NaCl}$ system $\left(-21.2{ }^{\circ} \mathrm{C}\right)$. In addition, the melting at $-56.6{ }^{\circ} \mathrm{C}$ indicates the presence of $\mathrm{CO}_{2}$ (Table $\left.4, T_{\mathrm{mCO} 2}\right)$. Thus, a $\mathrm{L} 1+\mathrm{L} 2+\mathrm{V}$ system made by $\left(\mathrm{H}_{2} \mathrm{O}+\mathrm{NaCl}\right)+\mathrm{CO}_{2}$ liquid $+\mathrm{CO}_{2}$ gas is deduced (aqueous-carbonic system). Fluid inclusions showing slightly lower temperatures (as low as $-57.7^{\circ} \mathrm{C}$, Position I, Table 4) pointing to the presence of other gases like $\mathrm{CH}_{4}$ or $\mathrm{N}_{2}$ in Position I. Traces from $\mathrm{N}_{2}$ were detected by Mata et al. (2001) using Raman spectroscopy at the fluid inclusions of the bottom part of the Urbion Group.

The broad bands around 1580 and $1355 \mathrm{~cm}^{-1}$ detected by Raman spectroscopy in some FIAs in Position I (Fig. 10) are respectively the D-band (disorder band) and the O-band (ordered band) of graphite (Wopenka \& Pasteris, 1993). The D-band indicates a disorder structure of this graphite (Wopenka \& Pasteris, 1993). Graphite can be formed as a result of the conversion of organic matter by increasing the temperature or as a precipitate of $\mathrm{C}-\mathrm{H}-\mathrm{O}$ fluids (Huizenga, 


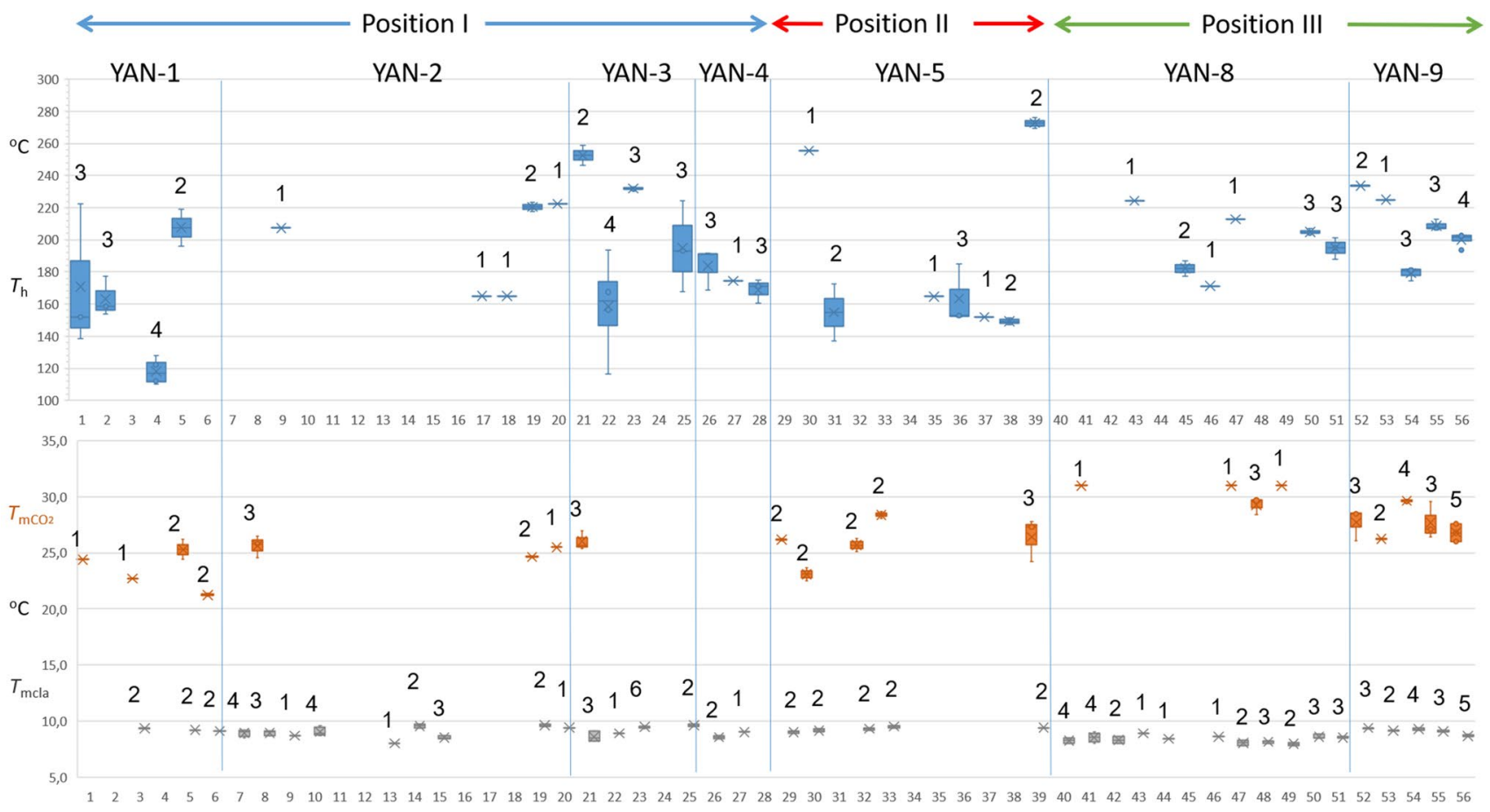

Fig. 9 Box and whisker graphic of $T_{\text {mcla }}\left({ }^{\circ} \mathrm{C}\right), T_{\mathrm{hCO}_{2}}\left({ }^{\circ} \mathrm{C}\right)$ and $T_{\mathrm{h}}\left({ }^{\circ} \mathrm{C}\right)$ data of the quartz veins. The $x$ axis represents the FIA number (see Supplementary material) and the number on the above of each box is the number of fluid inclusions in a particular FIA



Fig. 10 Raman spectra of one fluid inclusion in sample YAN-2, showing the characteristic bands of $\mathrm{CO}_{2}$ and a two broad bands around 1355 and $1580 \mathrm{~cm}^{-1}$ interpreted as D-band (disorder band) and O-band (order band) of disordered graphite. Modified from San José (2014). Intensity is expressed in arbitrary units (a.u.)

2011 and references herein). In our case, first option is possible as far as the host rock present organic material (Mantilla-Figueroa, 1999; Ochoa et al, 2007). Nevertheless, the second option is more likely since graphite is detected by Raman spectroscopy in all FI of a FIA, so is interpreted as precipitated within the FIs from the inclusion fluid (daughter mineral). Graphite probably precipitated during the cooling of the fluid inclusions (e.g.: Frezzotti et al, 1994; Cesare et al., 1995) after the hydrothermal process.

The irregular morphologies of fluid inclusions showing quartz re-entrants (Fig. 7c-f) can be interpreted in two ways: (1) As formed by partial necking down, in relation to the change in shape of FI over time, before fully achieve stable shapes (negative crystal shape). (2) Due to precipitation of quartz on the inclusion walls. Hurai and Horn (1992) and Van den Kerkhof and Hein (2001) explained the crystallization of newly formed quartz in fluid inclusions that have suffered fluid leakage. This leakage is compensated by quartz growth in the inclusion cavity. This second possibility is less likely since in the studied quartz veins no other textures related to natural partial or total decrepitation have been found (i.e. IF showing fracturing in their boundaries or decrepitation clusters around reequilibrated FI, see Figs. 3 and 4 in Hurai \& Horn, 1992).

The multiple pulses produced the different cementation episodes recorded with SEM-CL, explaining the coexistence of abundant FIAs with large $T_{\mathrm{h}}$ variations together with some FIAs showing narrow $T_{\mathrm{h}}$ range in positions I and II (Fig. 9). Some of the variation might be related to pressure 
fluctuations during FIA formation (Fall \& Bodnar, 2018), but when the range is very large additional reequilibration processes are required to explain this disparity. Thus, the FIAs with large $T_{\mathrm{h}}$ variations (Fig. 9, positions I and II) are constituted by reequilibrated fluid inclusions due to successive heating pulses. The reequilibration involves fluid leakage, probably water, as water is more mobile due to the higher polarity of the water molecules compared to gas (Kerkhof \& Hein, 2001). Nevertheless, these reheating episodes were probably related to the same hydrothermal event, as far as FIAs hosted in both older and newer quartz show similar petrographic and microthermometric characteristics. Regarding position III, the narrow $T_{\mathrm{h}}$ range within individual FIAs (Fig. 9) is pointing that these fluid inclusions have not suffered reequilibration processes.

Salinity, amount-of-substance fraction, partial density of the $\mathrm{CO}_{2}$ phase and total density of the fluid inclusions have been calculated for a system $\left(\mathrm{H}_{2} \mathrm{O}+\mathrm{NaCl}\right)+\mathrm{CO}_{2}$ liquid $+\mathrm{CO}_{2}$ gas using the program of Steele-MacInnis (2008). The $T_{\mathrm{h}}$ of each fluid inclusion was used for the calculation when it was available. If not, either the decrepitation temperature $\left(T_{\mathrm{de}}\right)$ or the volume fraction (\%) of the carbonic portion at $T_{\mathrm{hCO} 2}$ was considered. The Bodnar (1993) equation has been used for salinity calculation in the cases that no clathrate melting was observed (Supplementary material). Calculated salinities for inclusions in veins are between 0.6 and 9.2 mass \% (NaCl-eq.) and no tendency was detected from bottom to top (Table 4 and Supplementary material). Higher salinities are obtained in fluid inclusions in which no clathrate melting is observed [maximum 9.2 mass \% (NaCl-eq.), Supplementary material] than those in which this melting is observed [maximum 4.3 mass \% ( $\mathrm{NaCl}$-eq.), Supplementary material]. This can be due to the presence of non-observed clathrates, which retain part of the water producing an overestimation of the salinity. Thus, most reliable salinities are the ones of fluid inclusions in which clathrate melting is observed [0.6-4.3 mass \% (NaCl-eq.), Table 4].

The increase in $T_{\mathrm{hCO} 2}$ from bottom to top (Fig. 8c) indicates a decrease of the bulk densities of fluid inclusions towards the top of the section. Calculated partial densities of $\mathrm{CO}_{2}$ in equilibrium with the clathrate range from 0.10 to $0.42 \mathrm{~g} / \mathrm{cm}^{3}$ with mean and modal values of 0.27 and $0.33 \mathrm{~g} /$ $\mathrm{cm}^{3}$ respectively (Supplementary material). Calculated densities for the total fluid inclusions are between 0.88 and $1.00 \mathrm{~g} / \mathrm{cm}^{3}$, with mean and modal values of 0.96 and $0.97 \mathrm{~g} /$ $\mathrm{cm}^{3}$ respectively (Supplementary material).

Minimum entrapment pressures have been calculated using the ISOC program of Bakker (2003). The Bowers and Helgeson (1983) equation extended by Bakker (1999) has been chosen as best option. This equation is valid for $T_{\mathrm{h}}$ higher than ours $\left(350-600^{\circ} \mathrm{C}\right)$ but the isochores are quite linear so can be extended to lower $T_{\mathrm{h}}$. Obtained values are between 11 and $218 \mathrm{MPa}$, with mean value of $90.5 \mathrm{MPa}$, and most of the values are lower than $150 \mathrm{MPa}$ (Table 4).

There is strong pressure variation inside each FIA, even in the ones with narrow range in $T_{\mathrm{h}}$ (Supplementary material). This variation is related to the different $T_{\mathrm{h} \mathrm{CO} 2}, T_{\mathrm{mcla}}$ and $T_{\mathrm{h}}$ values inside each FIA. In the FIAs in which the pressure determination was possible (Supplementary material), these variations reach values of $\Delta T_{\mathrm{hCO} 2}=3.2^{\circ} \mathrm{C}, \Delta T_{\mathrm{mcla}}=0.9^{\circ} \mathrm{C}$ and $\Delta T_{\mathrm{h}}=35^{\circ} \mathrm{C}$ (absolute values). The pressure determination is very sensitive to the three parameters. For example, considering fluid inclusion 1 of YAN-9 (Supplementary material), a decrease of $T_{\mathrm{hCO} 2}=1^{\circ} \mathrm{C}$ with all the other parameters fixed implies a higher total density (calculated with the program Steele-MacInnis, 2008), producing an increase of $11.0 \mathrm{MPa}$ (calculated with ISOC, Bakker, 2003). A decrease in $T_{\text {mcla }}$ implies the same effect in higher amount $\left(\downarrow T_{\text {mcla }}=1^{\circ} \mathrm{C}: \uparrow 24.0 \mathrm{MPa}\right)$. On the contrary, a decrease in $T_{\mathrm{h}}$ produces a decrease in pressure $\left(\downarrow T_{\mathrm{h}}=1^{\circ} \mathrm{C}: \downarrow 1.7 \mathrm{MPa}\right)$.

In order to transform $T_{\mathrm{h}}$ to entrapment temperatures, a pressure correction is required using an independently obtained value of pressure (not the ones obtained from the fluid inclusions). Pressure determination based on burial depth would involve too many error-prone assumptions in a system controlled by fracture development with multiple crack and sealing events. For this reason, the obtained $T_{\mathrm{h}}$ of the present work $\left(109-282{ }^{\circ} \mathrm{C}\right.$, Table 4$)$ are interpreted as minimum entrapment temperatures, and no pressure correction has been applied.

The obtained $T_{\mathrm{h}}$ are in the same range as documented in previous studies (Table 2). All these $T_{\mathrm{h}}$ values (from this study and the previous ones) are lower than the temperatures calculated by Casquet et al. (1992) based on chlorite composition $\left(326 \pm 13^{\circ} \mathrm{C}\right)$ for the metamorphic peak. This difference can be explained considering that the $T_{\mathrm{h}}$ represents the minimum entrapment temperature of the fluid. In addition, Casquet et al. (1992) interpreted that the fluid inclusions in the quartz veins were formed during retrograde metamorphism.

The mean value of minimum entrapment pressures of the present work (90.5 MPa) is equivalent to the pressure calculated by Casquet et al. (1992) based on chlorite composition (100 MPa for the metamorphic peak). On the other hand, the maximum value of the present work (218 MPa, Table 4) is clearly higher, probably due to the thermal reequilibration of part of the fluid inclusions (which produced variations in $T_{\text {mcla }}, T_{\mathrm{hCO} 2}$, and $T_{\mathrm{h}}$ values). The pressure in the veins had to be lower than the lithostatic pressure to allow the fluid rise. Considering the thickness of DS $4+$ DS $5+$ DS 6 + DS 7 + DS 8 (4298 m, Fig. 4 of Omodeo-Salé et al., 2017) and a mean density of these units of $2678.3 \mathrm{~kg} / \mathrm{m}^{3}$ (Table 9.3 of Omodeo-Sale, 2014), the lithostatic pressure for the bottom of the Urbión Group for the moment of the metamorphism was $113 \mathrm{MPa}$. Thus, the fluid inclusions with 
higher pressures than $113 \mathrm{MPa}$ probably suffered strong reequilibration, and the calculated pressure values are unreliable. The most accurate values are those of Position III (up to $117 \mathrm{MPa}$, Table 4), as far as its FIAs have not suffered important reequilibration.

\subsection{Comparison of fluid inclusions in quartz grain overgrowths (host rock) and veins}

Figure 11 shows the comparison of minimum and maximum $T_{\mathrm{h}}$ values for fluid inclusions of the quartz grain overgrowths (in the host rock) and the veins with the line of maximum burial temperatures. This line has been calculated considering a theoretical burial gradient of $30^{\circ} \mathrm{C} / \mathrm{Km}$, plausible for a rift basin (Blackwell, 1971; Waples, 1980; Hitchon, 1984) and a superficial temperature of around $20^{\circ} \mathrm{C}$. Maximum burial temperatures would be $168^{\circ} \mathrm{C}, 154^{\circ} \mathrm{C}, 142{ }^{\circ} \mathrm{C}$ and $125^{\circ} \mathrm{C}$, for positions I, II, III and IV, respectively. Minimum $T_{\mathrm{h}}$ values of the host rock are very near to this line in all positions, but maximum $T_{\mathrm{h}}$ are far from it, with a difference of $60-110^{\circ} \mathrm{C}$ (Fig. 11). Thus, the minimum $T_{\mathrm{h}}$ values represent diagenetic temperatures, but most fluid inclusions of the overgrowths are related to the hydrothermal activity. The mixture of the diagenetic and the hydrothermal overprint plus thermal reequilibration processes are responsible of the large $T_{\mathrm{h}}$ variations of some FIAs (Fig. $5 \mathrm{c}$ ).

The maximum $T_{\mathrm{h}}$ in the quartz grain overgrowths from the host rock are not much lower than the $T_{\mathrm{h}}$ in the fluid inclusions in quartz veins (around $20^{\circ} \mathrm{C}$, see Fig. 11), pointing to the strong influence of the hydrothermal fluids on the host rock (Fig. 11). This fact, together with the observation that most of the host rock $T_{\mathrm{h}}$ are clearly higher than the calculated burial temperatures, indicates that during the hydrothermal activity the porosity of the sandstones was still partially open. This was due to the quartz-rich rigid frameworks of the Urbión Group sandstones (Arribas et al., 2014; Ochoa et al., 2007) and to a limited development of quartz grain overgrowths until this moment (Figs. 4c, d), although the burial depth was enough. As explained above, the calculated burial depth for the moment of the hydrothermal metamorphism is $4298 \mathrm{~m}$ for position I and $2860 \mathrm{~m}$ for position IV (4298-1438 m, Table 1). These burial depths are more than enough to allow for the development of diagenetic quartz grain overgrowths, which require minimum temperatures of $75-80^{\circ} \mathrm{C}$ (Walderhaug, 1994; Walderhaug et al., 2001; Worden \& Morad, 2000). The presence of hydrocarbons (Ochoa, 2006; Ochoa et al., 2007) may have played a role in the preservation of the porosity, limiting the development of diagenetic quartz syntaxial overgrowths.

Salinities of the fluid inclusions in the syntaxial overgrowths (2.7-16.3 mass \% (NaCl-eq.), Table 3 ) are generally higher than those of the veins ( 0.6 to 9.2 mass \% (NaCleq.), Table 4). This difference points that quartz cement and quartz vein fluid inclusions did not record all of the same fluids.
Fig. 11 Graphic of temperature $\left({ }^{\circ} \mathrm{C}\right)$ versus depth $(\mathrm{m})$, showing the minimum and maximum Th of fluid inclusions in quartz grain overgrowths and in quartz veins. They are compared with the calculated maximum burial temperature, considering a theoretical burial gradient of $30^{\circ} \mathrm{C} /$ $\mathrm{Km}$ and a superficial temperature of around $20^{\circ} \mathrm{C}$

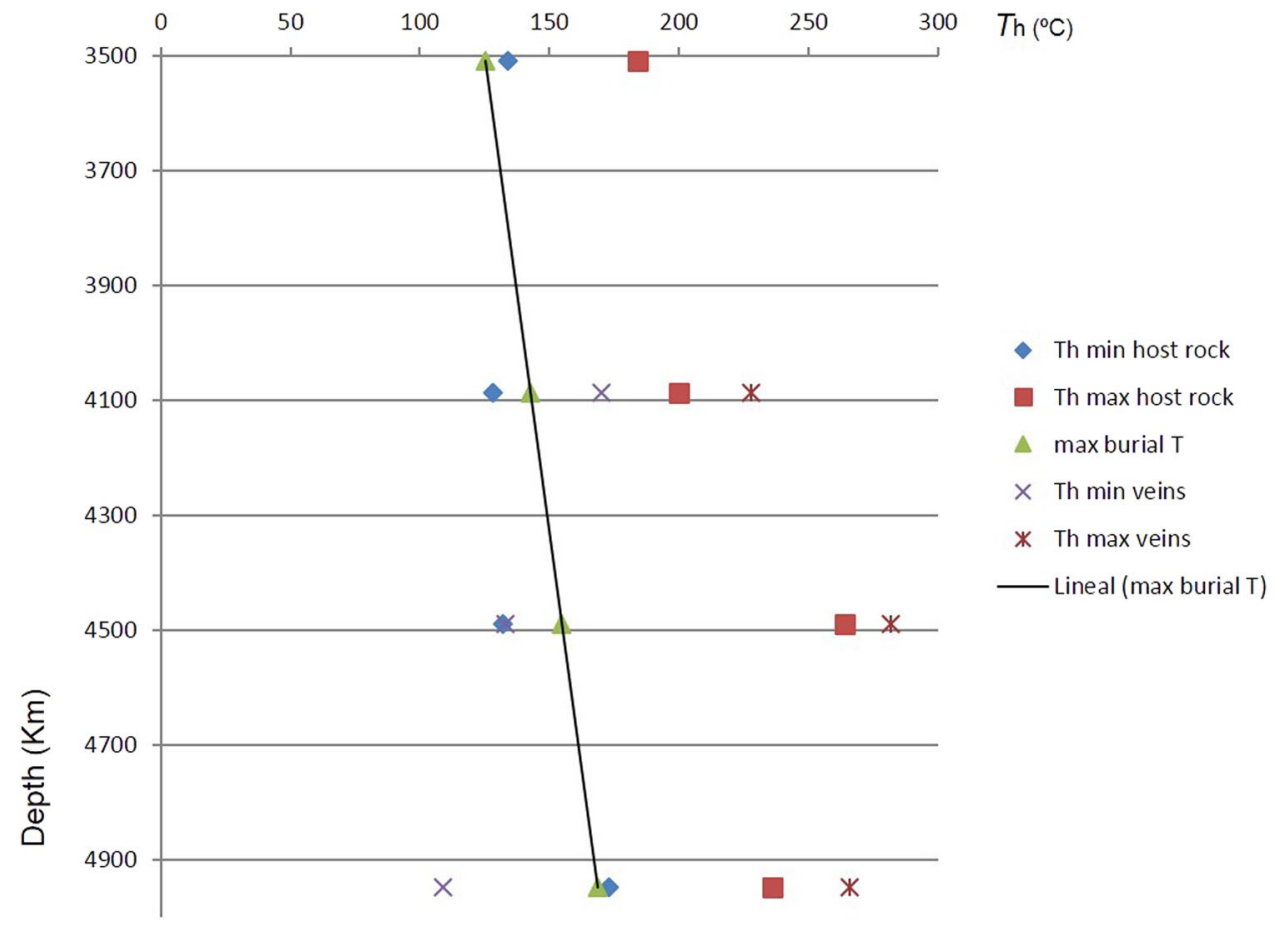




\subsection{Origin of the fluids in the context of the thermal evolution of the Iberian plate}

Regarding the provenance of the fluids, Mantilla-Figueroa (1999) suggests that they are related to the leaching of the Upper Triassic evaporitic Keuper facies due to the high values of $\mathrm{Cl} / \mathrm{Br}(1618.3-2263.1)$ and $\mathrm{Na} / \mathrm{Br}(1208.1-1499.7)$ measured by crushing of fluid inclusions of the quartz veins. Suarez-Gonzalez et al. (2016) found cartographic evidence of salt dome mobilizations in relation to the reactivation of late-variscan lineaments during syn-extensional mobilization. We propose that Keuper salts were also mobilized during post-extensional stage, during the Late Albian to Coniacian hydrothermal metamorphism, along the ramp of the detachment (Fig. 1d). For this reason, the depocentral areas, located close to the ramp, were affected by the hydrothermal fluids as suggested by Omodeo-Salé et al. (2017).

The metamorphism of the Cameros Basin (Late Albian to Coniacian, Casquet et al., 1992) is coeval to different geological processes: (1) Sea floor spreading in the western part of the Bay of Biscay (Albian-Santonian, Tugend et al., 2014, and references therein); (2) Crustal hyper-extension in the Pyrenean-Basque-Cantabrian rift system (Albian-Cenomanian, Tugend et al., 2014, and references therein); (3) Mantle exhumation in north Pyrenees (Albian-Cenomanian, Lagabrielle et al., 2010, and references therein); (4) High temperature and low-pressure metamorphism in the NE Pyrenees (Albian-Cenomanian, e.g.: Goldberg and Leyreloup, 1990); (5) Alkali basaltic volcanism in the northerm Iberian offshore and Pyrenean-Basque-Cantabrian rift system (Albian to Santonian, Castañares et al., 2001, and references therein; 110-85 Ma for the pyrenean magmatism, Montigny et al., 1986); (6) Very low-grade hydrothermalism in the Maestrat Basin (Salas et al., 2005) and associated Hg-Sb deposits $(85 \pm 3$ to $84 \pm 4 \mathrm{Ma}$, Tritlla \& Solé, 1999). Thus, the Cameros Basin metamorphism is related to what we suggest calling the "mid Cretaceous thermal event", in the context of the kinematic reorganization of the Iberian plate during Albian to Cenomanian.

\subsection{Implications for hydrocarbon and geothermal exploration in sedimentary basins affected by hydrothermal metamorphism}

This contribution confirms the importance of understanding deep-sourced fluids to explain thermal and chemical diagenetic changes in the sedimentary basins. Circulation of hot fluids may considerably change the porosity and permeability effectiveness of reservoirs rocks, due to massive precipitation of cements in the intergranular porosity. In addition, sealed fractures represent discontinuity planes which may strongly control the fluid circulation. Furthermore, hydrocarbons accumulated in rocks affected by hydrothermal metamorphism may be destroyed, as demonstrated in the Cameros Basin (Ochoa et al., 2007; OmodeoSalé et al., 2019). Therefore, understanding the circulation of hydrothermal fluids in a sedimentary basin can be the key in exploration when evaluating exploitable hydrocarbons resources. To recognize the thermal effect of hydrothermal fluid circulation is fundamental also when the stratigraphic section removed from erosion is estimated. If the high temperature attained in the rocks is due to circulation of fluids but is mistakenly interpreted as a burial effect, the magnitude of the erosion can be overestimated. The workflow proposed herein can be useful when the maturity of hydrocarbon source rocks are assessed in sedimentary basins affected by hydrothermalism.

To understand the circulation of hot deep fluids in exhumed paleo-sedimentary basins, such as the Cameros Basin, may also be relevant for evaluation of geothermal potential of present-day sedimentary basins formed in an analogue geodynamic and tectono-structural settings. The success of a low-enthalpy geothermal energy project, mostly developed in sedimentary basins contexts, is improved by a deep understanding of the fluid circulation system of the basin, which is firstly regulated by fractures, faults and host rock permeability. The case study presented herein shows that in a sedimentary basin evolving in an extensional setting, where deep low-angle extensional faults connect the sedimentary sequence with the deeper part of the lithosphere, the movement of hot hydrothermal fluids can be expected. Faults and fractures can be favorable targets for geothermal exploration in present-day sedimentary basins. On the other hand, this work shows that the host rock is also a site for movement of hydrothermal fluid, although low porosity and permeability would be a consideration for any geothermal prospect.

\section{Conclusions}

This study provides some keys to recognize hydrothermal processes in crack-seal quartz veins, as they have a mixture of FIAs with narrow and large $T_{\mathrm{h}}$ ranges. This is due to the reequilibration produced by successive hydrothermal pulses, increasing the original $T_{\mathrm{h}}$ of some fluid inclusions. The variations in $T_{\mathrm{mcla}}, T_{\mathrm{hCO}_{2}}$, and $T_{\mathrm{h}}$ values cause widespred pressure of entrapment interpretation. Thus, in these cases, the highest calculated pressures come from reequilibrated fluid inclusions and are probably unrealiable. Furthermore, the comparison of fluid inclusion microthermometry in quartz veins and in quartz grain overgrowths (from sandstone host rock) is a useful tool to determine the time span between both processes. In the study case, the porosity of the host sandstones was mostly still open and accessible to fluids during the vein cementation, probably due to the presence 
of hydrocarbons. The quartz grain overgrowths were mainly formed during the hydrothermal process as deduced by their high $T_{\mathrm{h}}$, which are not much lower than in the veins (around $20{ }^{\circ} \mathrm{C}$ ).

Finally, at local and regional scale, the data provided herein improve the understanding of the thermal history of the Cameros Basin, as well as the geodynamic evolution of the Iberian Plate in the middle Cretaceous. The hydrothermal metamorphism of the basin is coeval with the hyperextension of the northern margin of the Iberian plate in the middle Cretaceous. As a consequence, the paper contributes to the regional hydraulics of hyperextended margins. The hot deep fluids were channeled upward along pervasive shortlived regional structures transferring heat and chemicals. The circulation of deep hydrothermal fluids in the Cameros Basin confirms the anomalous thermal regime observed for this time in the entire northern part of the Iberian plate, in the context of its kinematic reorganization.

Supplementary Information The online version contains supplementary material available at https://doi.org/10.1007/s41513-021-00174-z.

Acknowledgements Funding for this research was provided by the Spanish Ministry of Economy and Competitivity, projects PGC2018094034-B-C21 and CGL2014-52,670-P, and by the research group Sedimentary Geology, Paleoclimate and Environmental Change (CLIMSED, Ref: 910198) of the Complutense University of Madrid. The authors would like to thank C. Casquet and R. Bodnar for their useful comments, R.H. Goldstein and an anonymous referee for their suggestions and M.A. Barajas and X. Arroyo for her technical support.

Funding Open Access funding provided thanks to the CRUE-CSIC agreement with Springer Nature.

\section{Declarations}

Conflict of interest On behalf of all authors, the corresponding author states that there is no conflict of interest.

Open Access This article is licensed under a Creative Commons Attribution 4.0 International License, which permits use, sharing, adaptation, distribution and reproduction in any medium or format, as long as you give appropriate credit to the original author(s) and the source, provide a link to the Creative Commons licence, and indicate if changes were made. The images or other third party material in this article are included in the article's Creative Commons licence, unless indicated otherwise in a credit line to the material. If material is not included in the article's Creative Commons licence and your intended use is not permitted by statutory regulation or exceeds the permitted use, you will need to obtain permission directly from the copyright holder. To view a copy of this licence, visit http://creativecommons.org/licenses/by/4.0/.

\section{References}

Alonso-Azcárate, J., Barrenechea, J. F., Rodas, M., \& Mas, R. (1995). Comparative study of the transition between very low-grade metamorphism and low-grade metamorphism in siliciclastic and carbonate sediments. Early Cretaceous, Cameros Basin (North Spain). Clay Minerals, 30, 407-419.

Alonso-Azcárate, J., Rodas, M., Bottrell, S. H., Raiswell, R., Velasco, F., \& Mas, R. (1999a). Pathways and distances of fluid flow during low-grade metamorphism: Evidence from pyrite deposits of the Cameros Basin, Spain. Journal of Metamorphic Geology, 17, 339-348.

Alonso-Azcárate, J., Boyce, A. J., Bottreu, S. H., MacAulay, C., Rodas, M., Fallick, A. E., et al. (1999b). Development and use of in situ laser sulfur isotope analyses for pyrite-anhydrite geothermometry: An example from the pyrite deposits of the Cameros basin, NE Spain. Geochimica et Cosmochimica Acta, 63, 509-513.

Arribas, J., González-Acebrón, L., Omodeo-Salé, S., \& Mas, R. (2014). The influence of the provenance of arenite on its diagenesis in the Cameros Rift Basin (Spain). In R. A. Scott, H.R. Smyth, A.C. Morton \& N. Richardson (Eds.), Sediment Provenance Studies in Hydrocarbon Exploration and Production (vol 386, pp. 63-73). UK: Geological Society, Special Publications

Bakker, R. J. (1999). Adaption of Bowers and Helgeson (1983) equation of state to isochore and fugacity coefficient calculation in the $\mathrm{H}_{2} \mathrm{O}-\mathrm{CO}_{2}-\mathrm{CH}_{4}-\mathrm{N}_{2}-\mathrm{NaCl}$ fluid system. Chemical Geology, $154,225-236$.

Bakker, R. J. (2003). Package FLUIDS 1. Computer programs for analysis of fluid inclusion data and for modelling bulk fluid properties. Chemical Geology, 194, 3-23.

Barrenechea, F. J., Rodas, M., \& Mas, J. R. (1995). Clay mineral variation associated to diagenesis and low-grade metamorphism of early Cretaceous sediments in the Cameros Basin, Spain. Clay Minerals, 30, 89-103.

Barrenechea, F. J., Rodas, M., Frey, M., Alonso-Azcárate, J., \& Mas, J. R. (2000). Chlorite, corrensite and chlorite-mica in Late Jurassic fluvio-Lacustrine sediments of the Cameros Basin of Northeastern Spain. Clays and Clay Minerals, 48(2), 256-265.

Barrenechea, F. J., Rodas, M., Frey, M., Alonso-Azcárate, J., \& Mas, J. R. (2001). Clay diagenesis and low-grade metamorphism of Tithonian and Berriasian sediments in the Cameros Basin. Clay Minerals, 36(3), 325-333.

Becker, S. P., Eichhubl, P., Laubach, S. E., Reed, R. M., Lander, R. H., \& Bodnar, R. J. (2010). A 48 m.y. history of fracture opening, temperature, and fluid pressure: Cretaceous Travis Peak Formation, East Texas basin. GSA Bulletin, 122(7-8), 1081-1093.

Blackwell, D. D. (1971). The thermal structure of the continental crust. In J. G. Heacock (Ed.), The structure and physical properties of the earth's crust geophysical monograph 14 (pp. 169-184). American Geophysical Union.

Bodnar, R. J. (1993). Revised equation and table for determining the freezing point depression of $\mathrm{H}_{2} \mathrm{O}-\mathrm{NaCl}$ solutions. Geochimica et Cosmochimica Acta, 57, 683-684.

Bowers, T. S., \& Helgeson, H. C. (1983). Calculation of the thermodynamic and geochemical consequences of nonideal mixing in the system $\mathrm{H}_{2} \mathrm{O}-\mathrm{CO}_{2}-\mathrm{NaCl}$ on phase relations in geological systems: Equation of state for $\mathrm{H}_{2} \mathrm{O}-\mathrm{CO}_{2}-\mathrm{NaCl}$ fluids at high pressures and temperatures. Geochimica Et Cosmochimica Acta, 47, 1247-1275.

Casas-Saínz, A. M., \& Gil-Imaz, A. (1998). Extensional subsidence, contractional folding and thrust inversion of the Eastern Cameros Basin, Northern Spain. Geologische Rundschau, 86, 802-818.

Casas-Saínz, A. M., Villalaín, J. J., Soto, R., Gil-Imaz, A., Del Río, P., \& Fernández, G. (2009). Multidisciplinary approach to an extensional syncline model for the Mesozoic Cameros Basin (N Spain). Tectonophysics, 470, 3-20.

Casas-Sainz, A. M., Del Rio, P., Mata, P., Villalain, J. J., \& Barbero, L. (2012). Comment on Gonzalez-Acebron et al. Criteria for the recognition of localization and timing of multiple events of hydrothermal alteration in sandstones illustrated by petrographic, fluid inclusion, and isotopic analysis of the Tera Group, Northern Spain. Int. J. Earth Sciences (2011) 100, 1811-1826. 
International Journal of Earth Science (Geologische Rundschau), 101, 2043-2048.

Casquet, C., Galindo, C., González-Casado, J. M., Alonso, A., Mas, R., Rodas, M., et al. (1992). El metamorfismo en la Cuenca de Los Cameros. Geocronología e Implicaciones Tectónicas. Geogaceta, 11, 22-25.

Castañares, L., Robles, S., Gimeno, D., \& Bravo, J. V. (2001). The submarine volcanic system of the Errigoiti formation (AlbianSantonian of the Basque-Cantabrian Basin, Northern Spain): Stratigraphic framework, facies, and sequences. Journal of Sedimentary Research, 71(2), 318-333.

Cesare, B. (1995). Graphite precipitation in C-O-H fluid inclusions: Closed system compositional and density changes, and thermobarometric implications. Contributions to Mineralogy and Petrology, 122(1), 25-33.

Davis, D. W., Lonoenstein, T. K., \& Spencer, R. J. (1990). Melting behavior of fluid inclusions on laboratory-grown halite crystals in the systems NaCl- $\mathrm{H}_{2} \mathrm{O}, \mathrm{NaCl}-\mathrm{KCl}-\mathrm{H}_{2} \mathrm{O}, \mathrm{NaCl}-\mathrm{MgCl}_{2}-$ $\mathrm{H}_{2} \mathrm{O}, \mathrm{NaCl}-\mathrm{KCl}-\mathrm{H}_{2} \mathrm{O}$. Geochimica et Cosmochimica Acta, 54, 591-601.

Diamond, L. W. (1994). Salinity of multivolatile fluid inclusions determined from clathrate hydrate stability. Geochimica Et Cosmochimica Acta, 58, 19-41.

Diamond, L.W. (2003). Introduction to gas-bearing aqueous fluid inclusions. In I. M. Samson, A. J. Anderson \& D. D. Marshall (Eds.), Fluid inclusions: analysis and interpretation (vol 32, pp. 101-158). Mineralogical Association of Canada, Short course series

Duncan, A., Hanks, C., Wallace, W. K., O’Sullivan, P. B., \& Parris, T. M. (2012). An integrated model of the structural evolution of the central Brooks Range foothills, Alaska, using structural geometry, fracture distribution, geochronology, and microthermometry. AAPG Bulletin, 96(12), 2245-2274.

Fall, A., \& Bodnar, R. J. (2018). How precisely can the temperature of a fluid event be constrained using fluid inclusions? Economic Geology, 113, 1817-1843.

Fall, A., Eichhubl, P., Cumella, S. P., Bodnar, R. J., Laubach, S. E., \& Becker, S. P. (2012). Testing the basin-centered gas accumulation model using fluid inclusion observations: Southern Piceance Basin Colorado. AAPG Bulletin, 96(12), 2297-2318.

Frezzotti, M. L., Di Vincenzo, G., Ghezzo, C., \& Burke, E. A. (1994). Evidence of magmatic $\mathrm{CO}_{2}$-rich fluids in peraluminous graphite-bearing leucogranites from Deep Freeze Range (northern Victoria Land, Antarctica). Contributions to Mineralogy and Petrology, 117(2), 111-123.

García-Lasanta, C., Oliva-Urcia, B., Román-Berdiel, T., Casas, A. M., \& Hirt, A. M. (2014). Understanding the Mesozoic kinematic evolution in the Cameros basin (Iberian Range, NE Spain) from magnetic subfabrics and mesostructures. Journal of Structural Geology, 66, 84-101.

Golberg, J. M., \& Leyreloup, A. F. (1990). High temperature-low pressure Cretaceous metamorphism related to crustal thinning (Eastern North Pyrenean Zone, France). Contributions to Mineralogy and Petrology, 104(2), 194-207.

Goldstein, R. H., \& Reynolds, T. J. (1994). Systematics of fluid inclusions in diagenetic minerals. SEMP Short Course 31. Tulsa, Oklahoma, USA, pp. 192.

González-Acebrón, L., Goldstein, R. H., Mas, R., \& Arribas, J. (2011). Criteria for recognition of localization and timing of multiple events of hydrothermal alteration in sandstones illustrated by petrographic, fluid inclusion, and isotopic analysis of the Tera Group, Northern Spain. International Journal of Earth Sciences, 100, 1811-1826.

González-Acebrón, L., Goldstein, R. H., Mas, R., \& Arribas, J. (2012). Answer to the comment of Casas et al. about González
Acebrón et al.'s (2011) paper. International Journal of Earth Sciences, 101, 2049-2053.

Guimerà, J., Alonso, A., \& Mas, J. R. (1995). Inversion of an extensional-ramp basin by a newly formed thrust: the Cameros Basin (N Spain). In J. G Buchanan and P.G. Buchanan (Eds.), Basin Inversion (vol 88, pp. 433-45). Geological Society, Special Publications

Guiraud, M., \& Seguret, M. (1985). A realising solitary overstep model for the late Jurassic-Early Cretaceous (Wealdian) Soria strike-slip basin (Northern Spain). In K. T. Biddle \& N. Christie-Blick (Eds.) Strike-Slip Deformation, Basin Formation, and Sedimentation (vol 37, pp. 159-175). Society of Economic Paleontologists and Mineralogists, Special Publications.

Hitchon, B. (1984). Geothermal gradients, hydrodinamics and hydrocarbon occurrences, Alberta Canada. AAPG Bulletin, 68(6), 713-743.

Hooker, J. N., Gomez, L. A., Laubach, S. E., Gale, J. F. W., \& Marrett, R. (2012). Effects of diagenesis (cement precipitation) during fracture opening on fracture aperture-size scaling in carbonate rocks. In J. Garland, J. E. Neilson, S. E. Laubach, \& K. J. Whidden (Eds.), Advances in carbonate exploration and reservoir analysis (Vol. 370, pp. 187-206). Geological Society Special Publications.

Huizenga, J. M. (2011). Thermodynamic modelling of a cooling C-O-H fluid-graphite system: Implications for hydrothermal graphite precipitation. Mineralium Deposita, 46(1), 23-33.

Hurai, V., \& Horn, E. E. (1992). A boundary layer-induced immiscibility in naturally re-equilibrated $\mathrm{H}_{2} \mathrm{O}-\mathrm{CO}_{2}-\mathrm{NaCl}$ inclusions from metamorphic quartz (Western Carpathians, Czechoslovakia). Contributions to Mineralogy and Petrology, 112(2), 414-427.

Lagabrielle, Y., Labaume, P., \& de Saint Blanquat, M. (2010). Mantle exhumation, crustal denudation, and gravity tectonics during Cretaceous rifting in the Pyrenean realm (SW Europe): Insights from the geological setting of the lherzolite bodies. Tectonics, 29, TC4012.

Laubach, S. E., Reed, R. M., Olson, J. E., Lander, R. H., \& Bonnell, L. M. (2004). Coevolution of crack-seal texture and fracture porosity in sedimentary rocks: Cathodoluminescence observations of regional fractures. Journal of Structural Geology, 26, 967-982.

Mantilla-Figueroa, L. C. (1999). El metamorfismo hidrotermal de la sierra de Cameros (La Rioja-España): Petrología, geoquímica, geocronología y contexto estructural de los procesos de interacción fluido-roca (pp. 361). Universidad Complutense, Madrid: Ph.D. thesis, pp. 361.

Mantilla-Figueroa, L. C., Casquet, C., \& Mas, J. R. (1998). Los paleofluidos del Grupo Oncala, Cuenca de Cameros (La Rioja, España): Datos de inclusiones fluidas, isótopos de oxígeno y SEM. Geogaceta, 24, 207-210.

Mantilla-Figueroa, L. C., Casquet, C., Galindo, C., \& Mas, J. R. (2002). El metamorfismo hidrotermal Cretácico y Paleógeno de la Cuenca de Cameros (Coordillera Ibérica, España). Zubía. Instituto De Estudios Riojanos, 14, 143-154.

Mas, R., Alonso, A., \& Guimerà, J. (1993). Evolución tectonosedimentaria de una cuenca extensional intraplaca: La cuenca finijurásicaeocretácica de Los Cameros (La Rioja- Soria). Revista De La Sociedad Geológica De España, 6(3-4), 129-144.

Mas, R., Benito, M. I., Arribas, J., Serrano, A., Guimerà, J., Alonso, A., et al. (2002). La Cuenca de Cameros: Desde la extensión finijurásica-eocretácica a la inversión terciaria-implicaciones en la exploración de hidrocarburos. Zubía. Instituto De Estudios Riojanos, 14, 9-64.

Mas, R., Benito, M. I., Arribas, J., Serrano, A., Guimerà, J., \& Alonso, A., et al. (2003). The Cameros Basin: From late Jurassic-early Cretaceous extension to tertiary contractional inversion-implications of hydrocarbon exploration. In $A A P G$ International Conference and Exhibition. Geological Field Trip 11 (pp. 52), Barcelona, Spain. 
Mas, R., García, A., Salas, R., Meléndez, A., Alonso, A., Aurell, M., et al. (2004). Segunda fase de rifting: Jurásico Superior-Cretácico Inferior. In J. Vera (Ed.), Geología de España (pp. 503-509). Sociedad Geológica de España-IGME.

Mas, R., Benito, M. I., Arribas, J., Alonso, A., Arribas, M. E., \& González-Acebrón, L., et al. (2011). Evolution of an intra-plate rift basin: the Latest Jurassic-Early Cretaceous Cameros Basin (Northwest Iberian Ranges, North Spain). In Post-Meeting field trips 28th IAS Meeting (pp. 117-154). Zaragoza, Spain

Mas, R., Benito, M. I., Arribas, J., Omodeo-Salé, S., Suarez-González, P., Quijada, I. E., et al. (2019). The cameros basin. In C. Quesada \& J. T. Oliveira (Eds.), The geology of Iberia: A geodynamic approach: The alpine cycle (Vol. 5, pp. 37-46). Springer.

Mata, M. P., Casas, A. M., Canals, A., Gil, A., \& Pocovi, A. (2001). Thermal history during Mesozoic extension and Tertiary uplift in the Cameros Basin, northern Spain. Basin Research, 13, 91-111.

Montigny, R., Azambre, B., Rossy, M., \& Thuizat, R. (1986). K-Ar study of cretaceous magmatism and metamorphism in the Pyrenees: Age and length of rotation of the Iberian Peninsula. Tectonophysics, 129(1-4), 257-273.

Müller, W., Aerden, D., \& Halliday, A. N. (2000). Isotopic dating of strain fringe increments: Duration and rates of deformation in shear zones. Science, 288, 2195-2198.

Ochoa, M. (2006). Procedencia y diagénesis del registro arenoso del Grupo Urbión (Cretácico Inferior) de la Cuenca de Cameros (Cordillera Ibérica septentrional). Universidad Complutense de Madrid: Ph.D. thesis, pp. 240.

Ochoa, M., Arribas, J., Mas, R., \& Goldstein, R. H. (2007). Destruction of a fluvial reservoir by hydrothermal activity. Sedimentary Geology, 202, 158-173.

Omodeo-Salé, S. (2014). Thermal and sedimentary modeling of an intraplate extensional basin: Cameros Basin, North Spain. Application for a hydrocarbon prospecting (pp. 481).Universidad Complutense, Madrid: Ph.D. thesis, pp. 481.

Omodeo-Salé, S., Guimerà, J., Mas, R., \& Arribas, J. (2014). Tectono-stratigraphic evolution of an inverted extensional basin: The Cameros Basin (north of Spain). International Journal of Earth Science, 103, 1597-1620.

Omodeo-Salé, S., Salas, R., Guimerà, J., Ondrak, R., Mas, R., Arribas, J., et al. (2017). Subsidence and thermal history of an inverted Late Jurassic-Early Cretaceous extensional basin (Cameros, North-Central Spain) affected by very low-to low-grade metamorphism. Basin Research, 9, 156-174.

Omodeo-Salé, S., Ondrak, R., Arribas, J., Mas, R., Guimerà, J., \& Martínez, L. (2019). Petroleum systems modeling in a fold-and-thrust belt setting: The inverted Cameros Basin North-Central Spain. Journal of Petroleum Geology, 42(2), 145-172.

Ramsay, J. G. (1980). The crack-seal mechanism of rock-deformation. Nature, 284, 135-139.

Salas, R., Guimerá, J., Mas, R., Martín-Closas, C., Meléndez, A., \& Alonso, A. (2001). Evolution of the mesozoic central iberian rift system and its cainozoic inversion (Iberian Chain). In W. Cavazza, A. H. F. R. Roberson, \& P. Ziegler (Eds.), Peri-tethyan rift/wrench basins and passive margins (Vol. 186, pp. 145-185). Memoires Du Museum National D'Histoire Naturelle.
Salas, R., Caja, M. A., Mas, R., Martín-Martín, J. D., Mas, R., \& Permanyer, A. (2005). Mid-Late Cretaceous volcanism, metamorphism and the regional thermal event affecting the Northeastern Iberian basins (Spain). In A. Arnaud-Vanneau. N. Arndt \& I. Zghal (Eds.), Global Events during the Quiet Aptian-Turonian Superchro (pp. 55-58). Grenoble, France

San José, A. (2014). Characterization of Sytems of Interest in Geochemical Processes. Universidad Complutense, Madrid: Master thesis, pp. 46.

Steele-MacInnis, M. (2008). Fluid inclusions in the system $\mathrm{H}_{2} \mathrm{O}-$ $\mathrm{NaCl}-\mathrm{CO}_{2}$ : An algorithm to determine composition, density and isochore. Chemical Geology, 498, 31-44.

Suarez-Gonzalez, P., Benito, M. I., Mas, R., Quijada, I. E., \& CamposSoto, S. (2016). Influencia del Keuper y de la estructuración tardivarisca en la arquitectura de las unidades sin-extensionales del borde norte de la Cuenca de Cameros. Geotemas, 16, 185-188.

Tritlla, J., \& Solé, J. (1999). A new dated Cretaceous hydrothermal event in the Iberian Ranges (E of Spain) and its significance within the Mesozoic thermic scenario in the Iberian Peninsula. Ore Geology Reviews, 15(4), 243-259.

Tugend, J., Manatschal, G., \& Kusznir, N. J. (2014). Spatial and temporal evolution of hyperextended rift basins: Implications for the nature, kinematics, and timing of the Iberian-European plate boundary. Geology, 43(1), 15-18.

Villalaín, J. J., Fernández-González, G., Casas, A. M., \& Gil-Imaz, A. (2003). Evidence of a cretaceous remagnetization in the Cameros Basin (North Spain): Implications for basin geometry. Tectonophysics, 377, 101-117.

Van den Kerkhof, A. M., \& Hein, U. F. (2001). Fluid inclusion petrography. Lithos, 55, $27-47$.

Walderhaug, O. (1994). Precipitation rates for quartz cement in sandstones determined by fluid inclusion microthermometry and temperature history modeling. Journal of Sedimentary Petrology, 60, 203-210.

Walderhaug, O., Bjørkum, P. A., Nadeau, P. H., \& Langnes, O. (2001). Quantitative modeling of basin subsidence cause by temperaturedriven silica dissolution and reprecipitation. Petroleum Geoscience, 7, 107-114.

Waples, D. W. (1980). Time and temperature in petroleum formation: Application of Lopatin's method to petroleum exploration. AAPG Bulletin, 64, 916-926.

Worden, R. H., \& Morad, S. (2000). Quartz cementation in oil field sandstones: a review of key controversies. In S. Morad \& R. H. Worde (Eds.), Quartz Cementation in Sandstones (Vol. 29, pp. 1-20). Oxford: Special Publications of the IAS.

Wopenka, B., \& Pasteris, J. D. (1993). Structural characterization of kerogens to granulite-facies graphite: Applicability of Raman microprobe spectroscopy. American Mineralogist, 78(5-6), 533-557.

Zinkernagel, U. (1978). Cathodoluminescence of quartz and its application to sandstone petrology. Contributions to Sedimentary Petrology, 8, 1-69. 